4 norden 



\section{CBA of Cycling}

TemaNord 2005:556 


\section{CBA of Cycling}

TemaNord 2005:556

(C) Nordic Council of Ministers, Copenhagen 2005

ISBN 92-893-1209-2

This publication can be ordered on www.norden.org/order. Other Nordic publications are available at www.norden.org/publications

Nordic Council of Ministers

Store Strandstræde 18

DK-1255 Copenhagen K

Phone (+45) 33960200

Fax (+45) 33960202

www.norden.org
Nordic Council

Store Strandstræde 18

DK-1255 Copenhagen K

Phone (+45) 33960400

Fax (+45) 33111870

\section{Nordic co-operation in the transport sector}

The overall, general objective of co-operation is to foster a Nordic transport sector characterised by efficiency, competitiveness, safety, sustainability, and equality. In order to attain these objectives with the resources available, co-operation will be focussed on four areas:

Sustainable Mobility, The Baltic Sea, Intelligent Transport Systems and Transport Safety.

\section{Nordic co-operation}

Nordic co-operation, one of the oldest and most wide-ranging regional partnerships in the world, involves Denmark, Finland, Iceland, Norway, Sweden, the Faroe Islands, Greenland and Åland. Cooperation reinforces the sense of Nordic community while respecting national differences and similarities, makes it possible to uphold Nordic interests in the world at large and promotes positive relations between neighbouring peoples.

Co-operation was formalised in 1952 when the Nordic Council was set up as a forum for parliamentarians and governments. The Helsinki Treaty of 1962 has formed the framework for Nordic partnership ever since. The Nordic Council of Ministers was set up in 1971 as the formal forum for co-operation between the governments of the Nordic countries and the political leadership of the autonomous areas, i.e. the Faroe Islands, Greenland and Åland. 


\section{Content}

Content 5

Preface $\quad 7$

Summary $\quad 8$

Major conclusions $\quad 8$

Recommendations 9

Sammanfattning 10

$\begin{array}{ll}\text { Huvudslutsatser } & 10\end{array}$

Rekommendationer 11

1 Introduction 13

2 Methods for CBA of cycling 15

2.1 Cost-benefit analyses of walking and cycling track networks in Norway 15

2.2 Benefits and costs of bicycle infrastructure in Sweden 20

2.3 Finnish guidelines for the assessment of walking and cycling projects 25

2.4 Cost Benefit Analysis of Cycling - Denmark 31

2.5 Valuing the mortality benefits of regular cycling 36

2.6 Discussions on methodological aspects 40

3 Policy relevance 49

3.1 National Cycling Strategy in Norway - Making Cycling Safe and Attractive 49

3.2 CBA's role in Swedish Planning 54

3.3 Cycling policy in Finland and relevance of CBA 59

3.4 Cycling, Environment, Exercise and Health 64

3.5 Transport, Health and Environment Pan-European Programme (THE PEP) 69

3.6 Discussions on the role of CBA in decision making 73

4 Conclusions and recommendations 75

4.1 Conclusions $\quad 75$

$\begin{array}{lll}4.2 & \text { Recommendations } & 78\end{array}$

References $\quad 81$

Appendix - Seminar Programme 83 



\section{Preface}

Investing in infrastructure for cycling has a number of effects often not included in ordinary Cost Benefit Analysis, CBA, for roads. It is therefore likely that special methods are needed to conduct CBA for cycling.

In February 2005 a Nordic seminar was held in Stockholm. The purpose of the seminar was to share and discuss these Nordic experiences in order to reach a common understanding and platform for further work. The current report summarises the knowledge of CBA of cycling in the Nordic countries and discusses the policy relevance of more advanced methods for cycle infrastructure planning. The report has been compiled by Gunnar Lind.

\section{Sven Hunhammar}

Swedish Environmental Protection Agency 


\section{Summary}

In February 2005 a Nordic seminar "CBA of cycling - current experieces in the Nordic countries" was held in Stockholm. The purpose of the seminar was to share and discuss the Nordic experiences concerning Cost-Benefit-Analysis in the area of cycling infrastructure in order to reach a common understanding and platform for further work. The current report summarises the state-of-the-art in the Nordic countries and the discussions held at the seminar.

\section{Major conclusions}

At the seminar it was agreed that comfort, security, public health effects, accidents, travel time and costs of cycling are the main direct effects that should be included in a CBA of cycling infrastructure.

Other effects as the reduction of external costs (maintenance, emissions, noise, accidents etc) for motorised transports, consequences for public transport, effects on transport of school children and short-term absence from work should also be included if these effects can be quantified. The assumptions made in the case studies are however uncertain. More evidence is needed to qualify these assumptions.

It was also agreed that the Public health benefits are great if it is possible to directly address inactive persons. The magnitude of the assumed health effects of activating inactive persons is similar between the countries. All participants also seem to agree that 30 minutes of cycling per day is necessary to achieve the health benefits. The link between measures to improve cycling and activating inactive people is however rather weak and more studies are needed to qualify this assumption.

There is also an agreement that effects on comfort and security also can play a big role in CBA of cycling. Just a few studies have directly addressed this issue. More evidence is needed to determine the correct magnitude of these effects.

It is very important for CBA of cycling to understand the demand effects of improving cycle infrastructure and comfort values of cycling. Understanding demand is the key to the health benefits as well as the effects on comfort and security. More studies in this field are necessary.

Average unit cost values used in the Nordic studies are summarised in section 4.1. There seems to be no big differences between the countries apart from travel time. These differences should be sorted out. It is important to control the value of time for cycling, cost and time elasticities in comparison with other transport modes. 
There is a big potential for cycling to improve public health, the environment and the attractivity of the cities. It is assumed in the Danish case study that the number of cycle trips shorter than $3 \mathrm{~km}$ can increase with $50 \%$ or more.

As the problem of obesity and physical inactivity is growing, there will be a great chance to promote cycling. In order to promote cycling it is necessary to make cycling safer and more attractive in the future.

\section{Recommendations}

The Nordic Council of Ministers is recommended to open a website where you can find the summary report and the contributions to the seminar and the national reports. There should also be a link to the report at the PEP and ECMT websites.

It is recommended to establish a network where interested parties can exchange views in methodological and policy issues of CBA of cycling. Such a network can accelerate dissemination of results and the development of the CBA method. A possibility is to bring this initiative to the newly established network for the promotion of health enhancing physical activity in Europe (HEPA Europe).

The Nordic countries and WHO are recommended to co-operate to get reliable and convincing results concerning demand effects, valuation of comfort and security and realistic health effects of cycling. All countries are recommended to check their handbooks and develop their approaches further based on the result of the methodological discussion.

Although some factors are uncertain, it is recommended to test the CBA method already today. The most reasonable application is probably on a strategic level for a network or a programme in a city, regarding the data needed to fulfil the CBA.

Data concerning cycling performance, flows, standard of cycle paths etc are needed to enable reliable CBA's of cycling. The quantification of cycling and walking (i.e. monitoring) is a critical weakness in many countries. All countries are recommended to check how data can be improved to allow fore comprehensive use of CBA of cycling.

There is a need to reach local authorities and have them involved in the key decisions. In order to obtain a widespread use, methods should be transparent and obvious. It is recommended to develop some reasonably sound "model" (spreadsheet) to facilitate the picking-up of CBA of cycling by local authorities.

The time is ripe for CBA of cycling, if we are critical and accept that we need more knowledge. The CBA of cycling should be further promoted nationally, in ECMT and other international fora. The knowledge that has been put together should also be used to further develop national health strategies and strategies concerning sustainable development. 


\section{Sammanfattning}

I februari 2005 hölls ett nordiskt seminarium "CBA of cycling - current experiences in the Nordic countries" i Stockholm. Syftet med seminariet var ökad kunskapsutbyte och att diskutera nordiska erfarenheter kring samhällsekonomiska kalkyler (CBA) rörande cykelinfrastruktur för att uppnå ömsesidig förståelse och en plattform för fortsatt arbete. Föreliggande rapport summerar nuvarande kunskapsläge i de nordiska länderna och diskussionerna som hölls på seminariet.

\section{Huvudslutsatser}

Deltagarna vid seminariet var eniga om att komfort, trygghet, hälsovinster, olycksrisker, restid och kostnader för cykling är de huvudsakliga direkta effekter som bör innefattas i kostnads-nytto-analyser (CBA) av cykelinfrastruktur.

Andra effekter som minskning av de externa kostnaderna (underhåll, emissioner, buller, trafikolyckor etc.) för biltrafik, konsekvenser för kollektivtrafiken, påverkan på skoltransporter och korttidsfrånvaro från arbete bör också tas med om dessa effekter kan kvantifieras. Antagandena som gjorts i praktikfallen är dock osäkra. Mer kunskap behövs för att säkerställa dessa antaganden.

Det finns en tydlig samstämmighet $i$ att de samlade kollektiva hälsovinsterna är stora om det är möjligt att direkt påverka inaktiva personer. Storleksordningen på de antagna hälsovinsterna av att aktivera tidigare inaktiva personer är lika mellan länderna. Alla deltagare tycktes också vara eniga om att en halvtimme cykling per dag krävs för att nå de eftersträvade hälsovinsterna. Sambandet mellan åtgärder för att förbättra cykling och att aktivera inaktiva personer är dock relativt svag och fler studier behövs för att detta antagande ska stå på fastare grund.

Det finns också koncensus om att effekter på komfort och trygghet kan spela en viktig roll i CBA för cykelinfrastruktur. Bara ett fătal studier har direkt fokuserat på denna fråga. Mer underlag behövs för att bestämma den korrekta storleksordningen av dessa effekter.

Det är väldigt viktigt för uppbyggnaden av CBA för cykling att förstå efterfrågeeffekterna av förbättrad cykelinfrastruktur och komfortvärden av cyklande. Att förstå efterfrågan är nyckeln till att bedöma såväl hälsoeffekterna som effekterna på komfort och trygghet. Mer studier behövs därför inom detta område.

Genomsnittliga enhetskostnader som används i de nordiska länderna har summerats i sektion 4.1. Det verkar inte finnas några större skillnader 
mellan länderna förutom när det gäller restid. Dessa skillnader bör redas ut. Det är viktigt att rimlighetskontrollera värdet av restid för cykling, kostnads- och tidselasticiteter i jämförelse med andra transportslag.

Det finns en stor potential hos cykling att kunna förbättra folkhälsan, miljön och städernas attraktivitet. Det antas t.ex. i den danska fallstudien att antalet cykelresor kortare än $3 \mathrm{~km}$ kan öka med minst 50\%

Eftersom problemet med fetma och fysisk inaktivitet tycks öka, kommer det också finnas en stor chans att göra PR för cykling för att öka hälsan. För att underlätta detta är det nödvändigt att göra cyklingen säkrare och mer attraktiv i framtiden.

\section{Rekommendationer}

Nordiska Ministerrådet rekommenderas öppna en portal där man kan hitta denna sammanfattningsrapport, bidragen till seminariet och de nationella referensrapporterna. Det bör också finnas en länk till rapporten på PEP:s och ECMT:s hemsidor.

Seminariedeltagarna rekommenderar vidare att det etableras ett nätverk där intresserade grupper kan diskutera metodiska och policyfrågor rörande CBA för cykelinfrastruktur. Ett sådant nätverk kan öka spridningen av resultat och utvecklingen av CBA-metodiken. En möjlighet är att lämna över detta initiativ till det nyligen etablerade nätverket till stöd för hälsoföbättrande fysiska aktiviteter i Europa (HEPA Europe).

De nordiska länder och världshälsoorganisationen WHO rekommenderas vidare att samarbeta för att erhålla trovärdiga och övertygande resultat när det gäller efterfrågeeffekter, värdering av komfort och trygghet samt realistisk hälsoeffekter av cykling. Alla länder rekommenderas att kontrollera sina handböcker i CBA och att utveckla sin metodik ytterligare med hjälp av metoddiskussionen i början av rapporten.

Även om en del faktorer är osäkra så rekommenderas att pröva CBAmetodiken I praktiken redan idag. Den rimligaste tillämpningen är troligen på strategsik nivå för ett cykelnätverk eller ett cykelprogram i en stad med hänsyn till data som bör finnas tillgängliga för att genomföra en CBA.

Data rörande cykelprestanda, flöden, vägstandard etc. behövs för att möjliggöra trovärdiga CBA:s för cykling. Kvantifieringen.av data om cykling och gående (dvs. uppföljning) är en kritisk svaghet $i$ ånga länder. Alla länder rekommenderas att undersöka hur data kan förbättras för att tillåta ett bredare användning av CBA för cykling.

Det finns behov att nå ut till kommunerna och få dem involverade i de centrala diskussionerna. För att uppnå bredare användning bör metodiken vara transparent och begriplig. Det rekommenderas att utveckla en rimligt sund "modell" (kalkylblad) för att underlätta praktisk användning av CBA inom kommunerna. 
Tiden är mogen för CBA för cykelinfrastruktur, om vi är kritiska och accepterar att vi fortfarande behöver lära oss mer. CBA för cykleinfrastruktur bör stödjas nationellt, inom ECMT och andra internationella fora. Kunskapen som samlats vid seminariet bör också användas för att vidareutveckla de nationella hälsostrategierna och strategierna för att nå en mer hållbar samhällsutveckling. 


\section{Introduction}

Investing in infrastructure for cycling has a number of effects often not included in ordinary Cost Benefit Analysis, CBA, for roads. It is therefore likely that special methods are needed to conduct CBA for cycling. Several studies and examples are now available in the Nordic countries, i.e. the TØI report by Kjartan Saelensminde, a new Nordic Council project in Sweden, a Finnish Guidebook and a Danish project.

In February 2005 a Nordic seminar was held in Stockholm. The purpose of the seminar was to share and discuss these Nordic experiences in order to reach a common understanding and platform for further work. The current report summarises the knowledge of CBA of cycling in the Nordic countries and discusses the policy relevance of more advanced methods for cycle infrastructure planning.

In chapter 2, current methods for Cost-Benefit Analysis, are presented. In the end of the chapter, the discussion at the seminar is reproduced. In chapter 3, the policy relevance of CBA for cycling is discussed. In chapter 4 , recommendations for the development and use of CBA for cycling in practice are presented. 



\section{Methods for CBA of cycling}

\subsection{Cost-benefit analyses of walking and cycling track networks in Norway}

Kjartan Sælensminde, Transportøkonomisk Institutt, Norway (absent at the seminar)

\subsubsection{Background}

Cost-benefit analyses (CBAs) are used to assess the impacts of road investment projects in Norway and many other countries. However, such analyses are not used to assess the impacts of measures designed to improve the safety and/or mobility of pedestrians and cyclists. The reason for this might be that important impacts such as insecurity and health effects are very difficult to make an adequate monetary valuation of and that the results of such CBAs therefore will be uncertain.

The recent study (Saelensminde, 2004) presents CBAs of walking and cycling track networks in the three Norwegian cities of Hokksund, Hamar and Trondheim. For the first time, CBAs take into account the fact that a change from travel by car to cycling or walking means reduced health costs, reduced external costs (e.g. air pollution and noise) from motorized traffic and reduced parking costs. A project group working on a National Cycling Strategy in Norway initiated the study of these more thorough CBAs. The motivation for undertaking the study is the Norwegian Parliament's request to the Government (Ministry of the Environment, 2001) in which the Government is asked to "prepare a National Cycling Strategy, the main goal of which is to make it safer and more attractive to choose a bicycle as a means of transport."

\subsubsection{Cost-benefit analysis at a strategic level}

The cost-benefit analyses of cycle track networks are made at an overarching strategic level. Designing the networks could have been included in the analyses, but this would have required detailed data about pedestrian and bicycle traffic on the different sections of the networks. Such detailed data are not yet available. Therefore, the analyses are based on average volumes of pedestrian and bicycle traffic on the cycle track networks in the three cities. 


\subsubsection{Benefit components of a truly complete cost-benefit analysis}

The CBAs include estimates of the following benefit components:

Traffic accidents. It is not known whether substituting walking or cycling for car and public transport use will result in more or fewer people injured in traffic accidents. A walking and cycle track network with safe crossing facilities is likely to reduce the number of traffic accidents involving pedestrians and cyclists. However, in order to avoid an overestimation of any benefits, we have assumed that the number of traffic accidents resulting in injury will remain unchanged because of the new walking and cycling tracks.

Travel time. Cycling on a walking and cycle track could conceivably reduce travel time compared to cycling on an ordinary sidewalk. Compared to cycling in the road, travel time will probably be the same or a bit longer on a walking and cycle track. In the CBAs we have assumed that travel times for pedestrians and cyclists remain unchanged because of the walking and cycle tracks. We assume that travel times for car drivers who do not substitute walking or cycling for driving are reduced in cities with traffic congestion. This is included in the analysis for Trondheim as reduced congestion costs.

Insecurity. Insecurity felt by pedestrians and cyclists moving along a road is included in the analyses at a cost of NOK 2 per kilometre. Assuming an average speed of $10-20 \mathrm{~km} / \mathrm{h}$ the cost of insecurity is about NOK 20-40 per hour for cyclists. Compared with the value assigned to travel time included in CBAs for crossing facilities of NOK 66 per hour, the estimated cost of insecurity seems to be of reasonable relative magnitude. However, the results from Hopkinson and Wardman (1996) that safety is more highly valued than time might indicate that the cost of insecurity in the CBAs is a lower bound estimate. Another explanation might be that excessively high valuations of travel time are used in Norwegian CBAs. Excessively high estimates of travel time savings are shown to be a result both because embedding effects are present, and because inconsistent choices are not handled properly in the Norwegian Stated Choice timevalue studies.

School bus transport. School children are offered transport to and from school if the route they would take to school is classified as too dangerous to walk or cycle along. We have assumed that $50 \%$ of these children will not need transport if walking and cycle track networks (with safe crossing facilities) are constructed. Information from the municipalities indicates that the reduction in the number of school children offered transport to and from school could be about 78 in Hokksund, 34 in Hamar and 120 in Trondheim. Based on an estimated cost of NOK 3.90 per 
child $/ \mathrm{km}$ the cost per child of transport to and from school is calculated to be NOK 4680 per year.

Less severe diseases and ailments and less short-term absence. As a benefit of extra physical activity (walking and cycling) we have assumed that short-term absence from work is reduced by 1 percentage point (from $5 \%$ to $4 \%$ ). With an average wage cost estimated at NOK 250,000 per year, this means an economic saving of NOK 2500 per year per person employed who becomes more physically active. Twenty five percent of all journeys are assumed to be trips to or from work. In order not to overestimate this benefit we have assumed that $50 \%$ of new pedestrians and cyclists will see improvements in their health due to the additional walking or cycling.

Severe diseases and ailments and long-term absence/disability. Moderate amounts of daily physical activity (e.g., 30 min walking or cycling) reduce the risk of premature mortality in general. In order not to overestimate this benefit we have only included risk reductions related to four types of severe diseases or ailments in the current cost-benefit analyses. The four types included are the diseases or ailments for which the Norwegian National Council on Nutrition and Physical Activity has estimated the costs to the society in the form of medical costs, treatment costs and potential productivity loss. The four types of diseases are cancer, high blood pressure, type- 2 diabetes and musculoskeletal ailments. In addition we have estimated costs due to welfare loss for people suffering from these diseases or ailments. The welfare loss is estimated to be $60 \%$ of the total costs. This is the same magnitude as for welfare loss for people injured in traffic accidents that the Norwegian Public Roads Administration uses in its CBAs of other road investments. In order not to overestimate the benefits of reduction in severe diseases and ailments we have assumed that $50 \%$ of new pedestrians and cyclists will enjoy better health due to the additional walking and cycling. In the cost-benefit analysis an economic saving of NOK 7300 per person per year who becomes " moderately more physical active", is included.

External costs of road transport. Included in the external costs are $\mathrm{CO} 2$-emissions, local emissions to air, noise, congestion and infrastructure costs. These are from Eriksen (2000) and are price-adjusted to NOK 1.36 and NOK 9.03 per kilometre for cars and buses, respectively, in major cities (Trondheim). For smaller cities (Hokksund and Hamar) the external costs are NOK 0.40 and NOK 4.57 per kilometre for cars and buses, respectively.

The Norwegian Public Roads Administration and The Ministry of Transport and Communication in their CBAs of transport investments use Eriksen's values for external costs. In an attempt to make the results from 
the CBAs of cycling and walking track networks comparable with results from CBAs of other transport investments we used the same values. In order not to overestimate the accident costs these are excluded from external costs of road transport. The reason is that we have assumed that the number of injury accidents is not affected by a substitution of walking or bicycling for car or public transport use.

Parking costs. Parking costs are estimated on the basis of rental prices companies pay for parking spaces in the different cities. Although most companies probably have lower parking costs than Europark's rental prices, these prices are the ones actually paid by the companies for parking space rental for their employees (and customers?). These parking costs are therefore judged to be a realistic estimate of companies' marginal cost of parking. In the analysis we have not included any reduction in the need of parking spaces for customers. Trips to and from work by car replaced by walking or cycling were assumed to reduce parking costs for businesses in Trondheim, Hamar and Hokksund by NOK 1165, NOK 560 and NOK 325 per month, respectively.

\subsubsection{Example of results}

In the cost-benefit analyses presented in the table and figure below, reduced costs related to severe diseases and ailments constitute approximately two-thirds of the total benefit in Hokksund and Hamar and approximately half of the total benefit in Trondheim. The benefit components' relative contributions to total benefits are also shown. It shows that considerable contributions come from reduced parking costs, reduced costs due to less short-term absence and reduced external costs of transport.

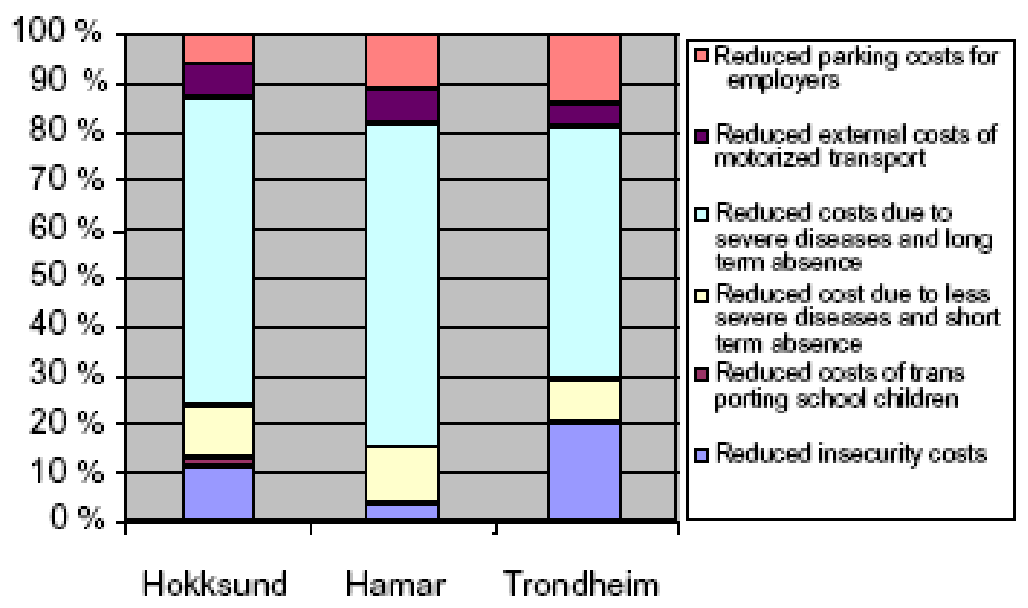


Benefits and costs (based on best estimates of future pedestrian and bicycle traffic) of investments in walking and cycling track networks in Hokksund, Hamar and Trondheim

\begin{tabular}{lccc}
\hline Benefit and cost components & Hokksund & Hamar & Trondheim \\
\hline Benefits of walking and cycling tracks (present value) & & & 0 \\
Accidents (assumed no change) & 0 & 0 & 0 \\
Travel time (assumed no change) & 0 & 2.7 & 107.6 \\
Reduced insecurity for current pedestrians & 4.2 & 6.1 & 398.2 \\
Reduced insecurity for current cyclists & 9.5 & 0.4 & 13.7 \\
Reduced insecurity for new future pedestrians & 0.5 & 2.3 & 100.7 \\
Reduced insecurity for new future cyclists & 3.5 & 1.1 & 3.6 \\
Reduced costs for transporting school children & 2.6 & 35.4 & 269.2 \\
Reduced costs related to less severe diseases and & 16.7 & & 1572.4 \\
$\quad$ ailments and less short-term absence & & 206.6 & 124.4 \\
Reduced costs related to severe diseases and ailments & 97.7 & 20.0 & 433.4 \\
Reduced external costs of motorized road transport & 9.4 & 34.6 & 3023.3 \\
Reduced parking costs for employers & 9.5 & 309.1 & \\
TOTAL BENEFIT & 153.7 & & 600.0 \\
& & 15.8 & 39.5 \\
Costs of walking and cycle tracks (present value) & & 1.0 & 127.9 \\
Capital costs & 23.6 & 3.4 & 767.4 \\
Maintenance costs & 1.6 & 20.1 & \\
Tax-cost factor, 20\% of budget costs & 5.0 & 14.34 & 2.94 \\
TOTAL COSTS & 30.2 & & \\
& & & \\
Net benefit/cost ratio & & & \\
\hline
\end{tabular}

Unit: NOK million (NOK 1 = USD 0.14).

\subsubsection{Conclusions and further research}

The CBAs presented are based on high, though realistic cost estimates, and "low" benefit estimates in order to prevent overestimates. The analyses are therefore judged to produce "down-to-earth", conservative estimates of the profitability to society of building walking and cycling track networks in Norwegian cities. CBAs conducted in this way constitute an adequate platform for politicians and other decision makers for addressing to the overall question of setting priorities and spending scarce public funds. With regard to the applicability of the analyses, profitability to society and perspectives with respect to setting priorities among transport investments, the best estimates of future pedestrian and bicycle traffic leave no doubt that building walking and cycling track networks in Hokksund, Hamar and Trondheim is beneficial to society.

The CBAs of walking and cycling track networks are based on a limited knowledge of many of the benefits and preliminary cost estimates included. In order to reduce uncertainties resulting from this limited knowledge, the following points are suggested as necessary further research:

- It will be essential to perform new valuation studies to improve valuations of accidents, travel time and insecurity.

- More information on the relationship between physical activity and the incidence and costs of different diseases and ailments will probably be available in the near future. This will make it possible to 
include more reliable cost estimates and include more types of severe diseases and ailments without double counting.

- Obtaining more accurate information on the number of accidents involving cyclists should have high priority in order to estimate correctly the costs of more bicycle use in the future.

\subsection{Benefits and costs of bicycle infrastructure in Sweden}

\section{Gunnar Lind, Movea Trafikkonsult; Christer Hydén, Lund Universi- ty and UIf Persson Institute of Health Economics, Sweden.}

\subsubsection{Introduction}

In order to carry out a cost-benefit-analysis, CBA, for an investment in bicycle infrastructure, we have to compare the benefits and the costs. It seems that new methods are necessary to carry out CBA's for bicycle investments as traditional methodology for road investments do not take into account a number of bicycle specific factors. The Nordic Council of Ministers, The Swedish Road Administration and the Swedish Environmental Protection Agency have taken the initiative to a project aiming at improvement of the decision basis for investments in bicycle infrastructure to such extent that they are comparable with other means of transport (Lind, 2005 and Naturvårdsverket, 2005).

\subsubsection{Experienced changes in demand}

Experience-based values of changes in demand from separate and integrated measures in bicycle traffic are reported. A broad and comprehensive programme of measures for bicycle traffic, consists of many types of measures: expansion of bicycle network, speed management, safe bicycle parks, improved maintenance, bicycle road signing and information. Several studies show that such programmes may give rise to considerable changes in mode choice and a measurable decrease in car traffic. In Odense in Denmark, cycling increased following the integrated bicycle programme with $11 \%$, of which half corresponded to a decrease in car traffic. In Troisdorf ${ }^{1}$ in Germany cycling increased with as much as $35 \%$, of which $4 / 5$ corresponded to a decrease in car traffic because of the extensive cycle project.

\footnotetext{
${ }^{1}$ situated close to Bonn
} 


\subsubsection{Cost of bicycle infrastructure}

The costs are often relatively concrete and values based on experience concerning investment and operation for different bicycle measures are reported. Cost values are based on experience from earlier bicycle projects, estimated values and documentation from contractors.

\subsubsection{Benefits of bicycle infrastructure}

Benefits are much more difficult to estimate than costs. The effects that have been identified in the project are summarised in the figure below. Mainly improvements are illustrated in the figure. A project can of course also lead to deteriorations. Other minor benefits are also possible to include and it is possible to structure the benefits in other ways. The cyclist will for instance pay attention to rapidity (short cuts), hazards (heavy traffic, lack of cycle track, bad interplay between cyclists and drivers), road signing, weather, road surface and risk of theft. The individual also pays attention to freedom (not bound to specified line, no timetable) and independence (own route choice), which influences the propensity to bicycle. Several of these benefits can be classified into the headings travel time, comfort, security or health.
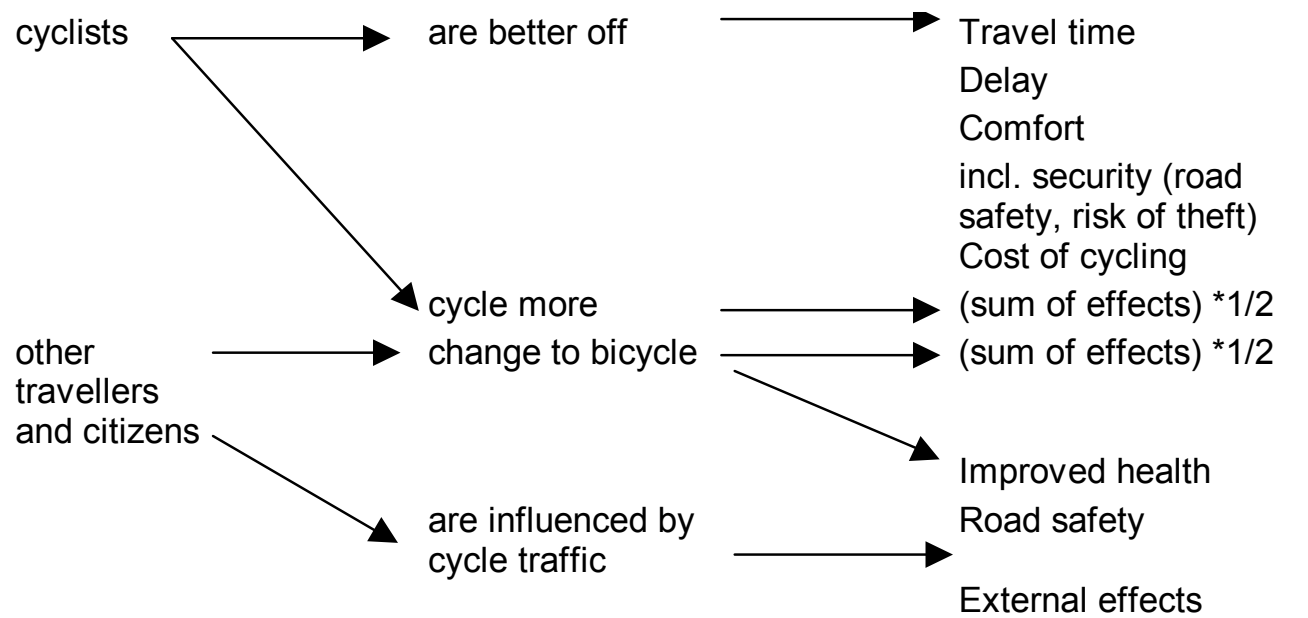

incl. security (road

safety, risk of theft)

Cost of cycling

The numbers in the figure above indicate effects that must be determined to estimate the total benefits of bicycle investments.

Travel time. It is proposed that gains in travel time and changes in comfort and security are separated in the CBA. The value of travel time is differentiated in dependence of the trip being carried out on cycle track, cycle path or in mixed traffic to catch differences in comfort and security. The travel time value of cycling on a cycle track is proposed to be set to 
$70 \mathrm{SEK} / \mathrm{h}(7.8 €)$, while $90 \mathrm{SEK} / \mathrm{h}$ for cycling in mixed traffic is regarded as reasonable.

Delay. A separate value is proposed for waiting time at intersections (140 $\mathrm{SEK} / \mathrm{h}$ ). Waiting time is experienced as more sacrificing than travel time, especially for necessary trips that have a specified destination. Different passengers experience of course waiting time in different ways, but the values that we propose are in parity with the values that are applied in traditional CBA for public transport.

Comfort incl. security. Travel time, comfort and travel costs influence the total experience of the trip, the so-called generalised cost. Experiencebased values of cycling speed, willingness-to-pay for comfort and security changes and costs of cycling are presented in the report. Some examples of values of comfort improvements:

\begin{tabular}{|l|c|}
\hline Measure & $\begin{array}{c}\text { Willingness-to-pay (WTP) }{ }^{2} \\
\text { SEK per original bicycle trip } \\
\text { in the analysed corridor }\end{array}$ \\
\hline $\begin{array}{l}\text { Comprehensive programme } \\
\text { for cycling } \\
\text { (cycling network, parking, campaigns } \\
\text { etc) }\end{array}$ & $10-20$ \\
\hline $\begin{array}{l}\text { Stand-alone separated high stan- } \\
\text { dard cycle corridor }\end{array}$ & $5-10$ \\
\hline Improved surface quality (smoothness) & $5-10$ \\
\hline Separate cycle path & $3-5$ \\
\hline Improved winter road maintenance & $1-3$ \\
\hline Safe cycle parking & $1-3$ \\
\hline Road signing/road marking & $0.5-2$ \\
\hline
\end{tabular}

Cycling operating costs. Operation costs for cycling consist of costs for insurance alternatively theft, repair and maintenance. These costs can be estimated to till 0.20 SEK per cycle kilometre. If we add estimated capital costs we sum up to a total cost of around 0.60 SEK per cycle kilometre.

Increased cycling for habitual cyclists. This benefit is calculated as the consumer's surplus. According to the "rule of the half" it is conventionally assumed that this benefit amount to half the change of the generalised travel (sum of travel time, comfort and costs). The argument is that

\footnotetext{
${ }^{2}$ Willingness To Pay (WTP) is measured by studying actual choices (revealed preferences, RP) or by enquiries (stated preferences, SP). $1 \mathrm{SEK}=0.11 €$, Dec 2004 .
} 
the first new cycle trip will result in a benefit that is almost the same as for earlier cycle trips while the last one results in a benefit that is close to zero. Half the change in the generalised travel cost will therefore be a good approximation of the average benefit.

Generated cycle trips for travellers transferring to cycling. The benefit is calculated in the same manner as for increased cycling for habitual cyclists.

Health improvements for new cyclists. In order to deduce the relationship between bicycle measures and medical costs, we must run through several mental steps. Bicycle measures lead to more cycling, more cycling leads to fewer inactive persons and decrease in obesity, decrease in inactivity and obesity lead to decrease in medical costs and excess morbidity. The current knowledge is deficient, but improvements come fast. New international published literature is presented in the report. The overall estimation for Swedish conditions is that the decreased cost for an activated inactive person in the age of 50-60 years amount to 12000 SEK per year.

The effects of increased cycling depend on how well it is focused on activating the group of older persons that earlier were totally inactive. For separate bicycle projects without special efforts to reach older and inactive persons, a value of around 2600 SEK per generated cyclist may seem reasonable. In a case where a focussed effort is made to increase exercise by cycling for older inactive people, a maximum value of 8300 SEK per generated cyclist may be adequate.

Road safety. The road safety is estimated according to conventional methods. The uncertainty in this estimate is however great. The review of bicycle accidents at intersections shows a best value of $42 \%$ improvement and a worst value of $78 \%$ deterioration (increase in number of accidents). The cause of the big variation is that the numbers of accidents before and after are relatively small and random changes give big turns in the percentages. Substantial improvements seem to arise if bicycle traffic is separated from other traffic. Increased bicycle traffic can of course lead to more bicycle accidents, but also influence both pedestrian and car traffic. The total effect can therefore be either positive or negative.

Decreased external effects for society. Indirect effects for society can arise from a transfer of especially car traffic. These effects consist of maintenance, emissions, noise, accidents etc. Major changes in car traffic can also lead to restructuring of urban environment, which in turn can influence parking conditions and land use in general. 


\subsubsection{Hypothetical CBA}

In the report there is a hypothetical example of a CBA that is used to summarise the methodology. This example will during the winter $2004 / 05$ be supplemented by case studies from real investments in Sweden.

\begin{tabular}{|c|c|c|c|c|}
\hline $\begin{array}{l}\text { Effect, per year } \\
\text { Best estimation }\end{array}$ & Change & Value & $\begin{array}{l}\text { Yearly cost, } \\
1000^{\prime} \text { SEK }\end{array}$ & $\begin{array}{l}\text { Yearly benefit, } \\
1000 \text { 'SEK }\end{array}$ \\
\hline \multicolumn{5}{|l|}{ Change in generalised cost } \\
\hline Savings in travel time, $\min /$ trip & 0,8 & $1,50 \mathrm{SEK} / \mathrm{min}$ & & 250 \\
\hline Reduced delay, min/trip & 1,0 & 2,33 SEK/min & & 530 \\
\hline Increased comfort and security, SEK/trip & 18 & & & 3960 \\
\hline Decreased bicycle costs, SEK/trip & 0,12 & & & 30 \\
\hline $\begin{array}{l}\text { Increased cycling for cyclists, SEK/ new } \\
\text { trip }\end{array}$ & 10,80 & & & 20 \\
\hline $\begin{array}{l}\text { New cyclists, SEK/ new trip } \\
\text { Indirect effects for society }\end{array}$ & 10,80 & & & 210 \\
\hline Health, SEK/ new trip & 11,70 & 2600 SEK/year & & 90 \\
\hline Road safety SEK/trip & 2,30 & $\begin{array}{c}\text { 0,8-1,8 } \\
\text { MSEK/accident }\end{array}$ & & 930 \\
\hline External effects, SEK/ reduced trip by car & 4:00 & $\begin{array}{c}0,45 \\
\text { SEK/vehiclekm }\end{array}$ & & 70 \\
\hline \multicolumn{5}{|l|}{ Costs } \\
\hline Investments & & 35 years life-time & 520 & \\
\hline Operation and maintenance & & & 150 & \\
\hline SUMMA & & & $\mathrm{K}=670$ & $\mathrm{~N}=6090$ \\
\hline
\end{tabular}

In our example, the benefit amounts to nearly nine times the capital cost of investment, operation and maintenance. We have deliberately included a number of benefit items in the example partly to illustrate the process of calculation. In reality, travel time savings seems to be considerably smaller than in the example.

Bicycle investments included in a comprehensive package of different measures might however be very profitable. The benefit of the improved cycling conditions in the hypothetical example is greatest for increased comfort (incl. security), road safety, and travel time savings (incl. delay). The impact on health is much to our surprise not so dominating as in the work by Saelensminde (2002) in Norway.

\subsubsection{Conclusions and further research}

The report gives an overview of the state-of-the-art concerning the calculation of various factors. Values are also proposed for a number of ef- 
fects. We recommend for current use the following three values in planning of bicycle traffic investments:

- Improvement in health per new cyclist: 2600 SEK/year (290€)

- Value of time for cycling in mixed traffic: 90 SEK/year (10€)

- Comfort improvement of a cycle track: 1.20 SEK per kilometre and cyclist $(0.13 €)$

The report shows that it is possible to develop a methodology to carry out CBA for cycle infrastructure, but also that there are a number of uncertain factors, where more knowledge is needed. The most important factors to discuss are:

- Changes in demand

- Willingness-to-pay for comfort improvements

- The possibility in practice to achieve improvements in public health

- Road safety effects of bicycle tracks and improved intersections

- The value of travel time for cyclists

\subsection{Finnish guidelines for the assessment of walking and cycling projects}

\section{Risto Saari, Ministry of Transport and Communications, Heikki Metsäranta, Strafica Ltd and Juha Tervonen, JT-Con, Finland}

\subsubsection{General famework}

The Finnish guidelines for the assessment of major transport infrastructure projects (so-called YHTALI-framework i.e. the Guidelines for Evaluating the Social and Economic Costs and Benefits of Infrastructure Investments) were presented in 1994 and they have been recently revised. The general guidelines contain so-called unit values for estimating the various impacts (emissions, noise, time effect, vehicle costs, accidents, change in modal split and other social and economic impacts) of infrastructure investments (Metsäranta, 2004).

Change in modal-split is the main objective for investment programmes, improvement of the level of service is most important for individual projects. For other transport projects impacts on walking and cycling is not the main objective, but it is interesting to have an indication of positive or negative impacts. Primary impacts can be classified as qualitative or quantitative. Qualitative impacts are comfort, feeling of safety etc. Quantitative impacts are travel-time, number of accidents etc. It is important to define relevant alternatives. The reference alternative can either be a do nothing alternative or a do minimum alternative. 


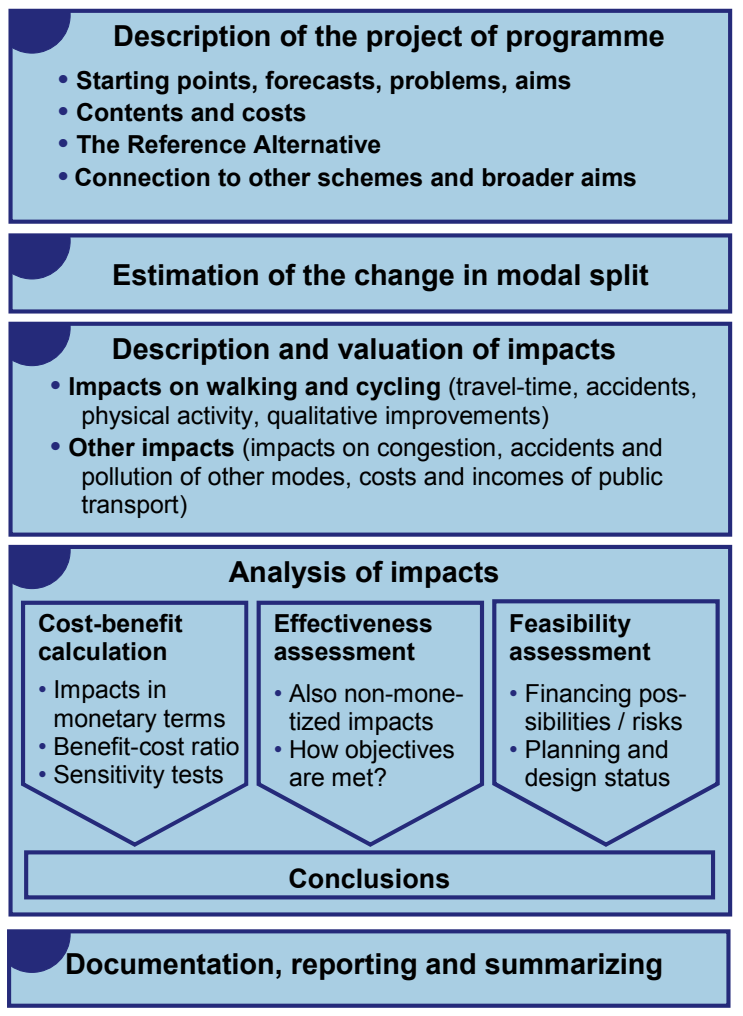

As regards the other environmental, social and economic benefits of cycling and walking investments, it is used those unit values that are presented in the above mentioned general guidelines for evaluating the social and economic costs and benefits of transport infrastructure projects (i.e. so-called YHTALI framework). ) These guidelines contain unit value indexes for emission costs, noise, traffic accidents, time costs and other social impacts. These unit value indexes are also applicable for evaluating the impacts of cycling investments. The structure of the calculation according to the guidelines is illustrated beneath. 


\section{A) Change in modal-split}

- Investment costs

- Change of consumer surplus

- Those who continue to walk or cycle

- Those who start to walk or cycle

- Those who continue to drive a car

- Change of producer surplus

- Operating costs (incl. school buses)

- Ticket revenues

- Health benefits

- Due to increased physical activity

- Change in externalities

- Costs of accidents, pollution, congestion

- Maintenance costs

- Residual value

\section{B) No change in modal-split}

- Investment costs

- Change of consumer surplus

- Those who continue to walk or cycle

- Change in externalities

- Costs of accidents

- Maintenance costs

- Residual value

\subsubsection{Adjusted framework for assessment of cycling and walking}

Even though the general guidelines (presented within YHTALIframework) are in principle feasible for evaluating the costs and benefits of cycling and walking investments, there are certain aspects that are not in an adequate way covered within this general framework. This concerns especially, on the one hand, the positive health impacts of cycling and walking, and, on the other hand, the time benefits received that have a high status when evaluating the positive impacts of motorised transport investments. In order to adjust the general assessment framework also for evaluating cycling and walking investments, the Finnish Ministry of Transport and Communications launched in 2003 a project to develop guidelines for the assessment of walking and cycling investments. On the basis of this work the Ministry of Transport and Communications published in May 2004 a manual containing guidelines for a framework for assessing the costs and benefits of programmes, investment projects and other measures concerning walking and cycling.

\subsubsection{Health benefits}

The evaluation of health impacts was acknowledged as a main factor when adjusting the general framework of transport infrastructure investments in order to fit also for evaluation of cycling and walking investments (Tervonen and Oja, 2005). The adjusted framework that was presented in May 2004 within the new guidelines for the assessment of walking and cycling projects uses the results of the Norwegian study (Saelensminde, 2002). Therefore, the Ministry of Transport and Communications has proposed that the municipalities and the Finnish Road Administration use so far the unit value of 1200 euros/person/year when calculating the health benefits of certain cycling or walking investment project. 
The Ministry of Transport and Communications considers that there is a political need for proceeding in a pragmatic way in order to include the health impacts in assessment procedures, even though there is not at this stage national quantitative data on health impacts to provide for unit value approach. Therefore, in its new research programme on cycling and walking the Ministry has proposed that increasing knowledge on quantified health impacts of cycling and walking should be one of the priority research areas in the forthcoming years. Epidemiological and economic data should be submitted to serve policy making. Economic evidence on the benefits of physical activity is needed in impact assessment of e.g. programs for promoting physical activity, construction of bicycle/pedestrian infrastructure and transport pricing. Ignoring the benefits of physical activity leads to underrating an important aspect of developing transport systems.

\subsubsection{Critical points}

Critical points in the framework are: consideration of thresholds for health impacts of walking and cycling, performance measurement with respect to the thresholds, epidemiological challenge of simultaneously quantifying the health impacts of physical activity for a range of diseases and other health risks and generalised valuation of the outcomes of improved health.

Health benefits are not self-evident. The rate, duration and intensity of physical activity are criteria for health impacts. The minimum dose that improves (and sustains) health is half an hour of moderately intense physical activity on most days of the week. The daily dose can also be received as a sum of intervals each lasting at least ten minutes at a time.

As energetic walking and cycling fulfil the requirements on intensity, daily mobility is ideal for improving and sustaining good health, taken that the duration and regularity of active intervals are sufficient.

The threshold is important for consideration, since impact assessment of transport projects is based on analysing mobility impacts (performance) measured in changes in person-kilometres (or travel time). It is critical, that the kilometres (or minutes) generated by walking and cycling projects (or other initiatives) exceed the above thresholds.

Only those kilometres, that exceed the threshold criteria of health benefits and which are produced by formerly inactive or less active individuals, qualify for CBA. Pedestrian and cyclists shifting from one route to another do not experience any additional dose of health improving physical activity. Also there are small amounts of new performance, that do not exceed the threshold, and they do not qualify for CBA. 


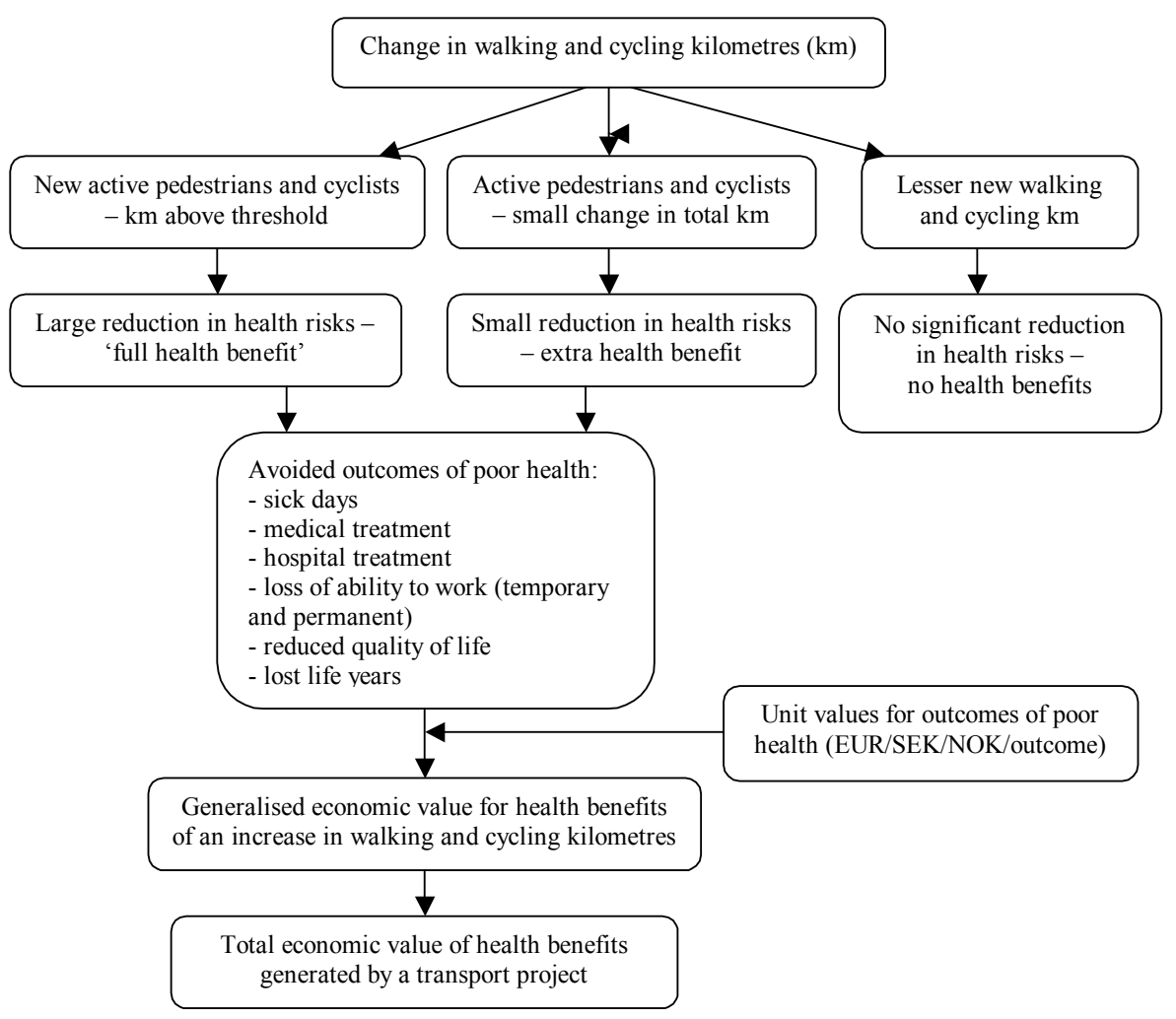

The epidemiological challenge of health impact assessment in transport appraisal is how to lump different types of diseases and other risks into an aggregate figure which represents the general improvement of health generated by an increase in walking and cycling. The Norwegian values in the pilot study by Saelensminde (2002) have so far been adopted in Finland as these follow the framework presented above to a large extent. Experiments on testing the framework for health impacts with default data derived from e.g. Nordic pre-studies are underway in Finland, but it is acknowledged, that the framework does not yet perform up to satisfactory scientific demands.

\subsubsection{Example of results}

A case study was made for Turku with two alternatives in which the share of cycling was increased from $37 \%$ up to $40 \%$ and $44.5 \%$ respectively by means of investments in road infrastructure. 


\begin{tabular}{|l|c|c|}
\hline & $\begin{array}{c}\text { The share of walking } \\
\text { and cycling } \\
\mathbf{3 7 \% =} \mathbf{4 0} \%\end{array}$ & $\begin{array}{c}\text { The share of walking } \\
\text { and cycling } \\
\mathbf{3 7 \%}=\mathbf{4 4 , 5 \%}\end{array}$ \\
\hline Investment & $-34,6 \mathrm{M} €$ & $-34,6 \mathrm{M} €$ \\
\hline Health benefits & $97,5 \mathrm{M} €$ & $260 \mathrm{M} €$ \\
\hline Reduction of emissions & $0,9 \mathrm{M} €$ & $2,6 \mathrm{M} €$ \\
\hline Reduction of congestion & $1,7 \mathrm{M} €$ & $4,8 \mathrm{M} €$ \\
\hline Maintenance & $-2,7 \mathrm{M} €$ & $-2,7 \mathrm{M} €$ \\
\hline Reduction of wear and tear & $0,1 \mathrm{M} €$ & $0,3 \mathrm{M} €$ \\
\hline Net benefit-cost ratio & $\mathbf{2 , 9}$ & $\mathbf{7 , 7}$ \\
\hline
\end{tabular}

\subsubsection{Conclusions and further research}

The following conclusions can be drawn from the framework and the case studies:

- The cost-benefit framework developed for motorized transport is generally applicable for "slow modes"

- The calculation is more challenging due to modal-shifts $=>$ confusion is expected

- Basic data of the volumes of walking and cycling is generally lacking

- Tools for forecasting and modelling pedestrian and cycle-flows are needed

- The "success factor" is the valuation of health benefits $=>$ so far the value is borrowed from Norway, national research is needed

Some important questions have been raised as a result of the project, which must be discussed in order to prioritise further research:

- Data and modelling of walking and cycling?

- Value of time when walking and cycling?

- The estimation of the consumer surplus ("rule of the half" or model $/ \log$ sum)?

- The valuation of long-term benefits of promoting walking ad cycling (more compact community structures etc.)? 


\subsection{Cost Benefit Analysis of Cycling - Denmark}

\section{Thomas Krag, Mobility Advice}

\subsubsection{Background}

Cost-benefit-analyses have been made in Denmark in the report from the Danish Ecological Council.: "Cycling, Environment, Exercise and Health" (Krag 2005 and Ege C et al, 2005). More cycling would enhance the health of the Danish population. Less people would suffer from cardio-vascular diseases, diabetes 2, osteoporosis, and certain forms of cancer. In addition, public investments in cycle-initiatives would have a high socio-economic yield. Such investments should therefore have high priority in the government's efforts to stimulate physical exercise and public health. Funding should be earmarked, so that municipalities interested in promoting cycle initiatives can apply for the financial means.

\subsubsection{Benefits of cycling}

Physical inactivity. Bicycling presents a solution to a number of problems. Transportation requirements, health as well as pollution problems can be tackled simultaneously. In wealthy parts of the world, there is much focus these days on physical inactivity and obesity; and the reason is obvious: these problems threaten common health. Comprehensive studies from several countries all speak the same language: physical inactivity is a problem that, in terms of surplus hospitalization expenditure, equals alcoholism, and is half as expensive as smoking. Judged by the mortality rate alone, inactivity is as dangerous as smoking. Health authorities have sounded the alarm and recommend half an hour of physical exercise each day for adults, and one hour for children. This exercise should at least be on the level of brisk walking. 


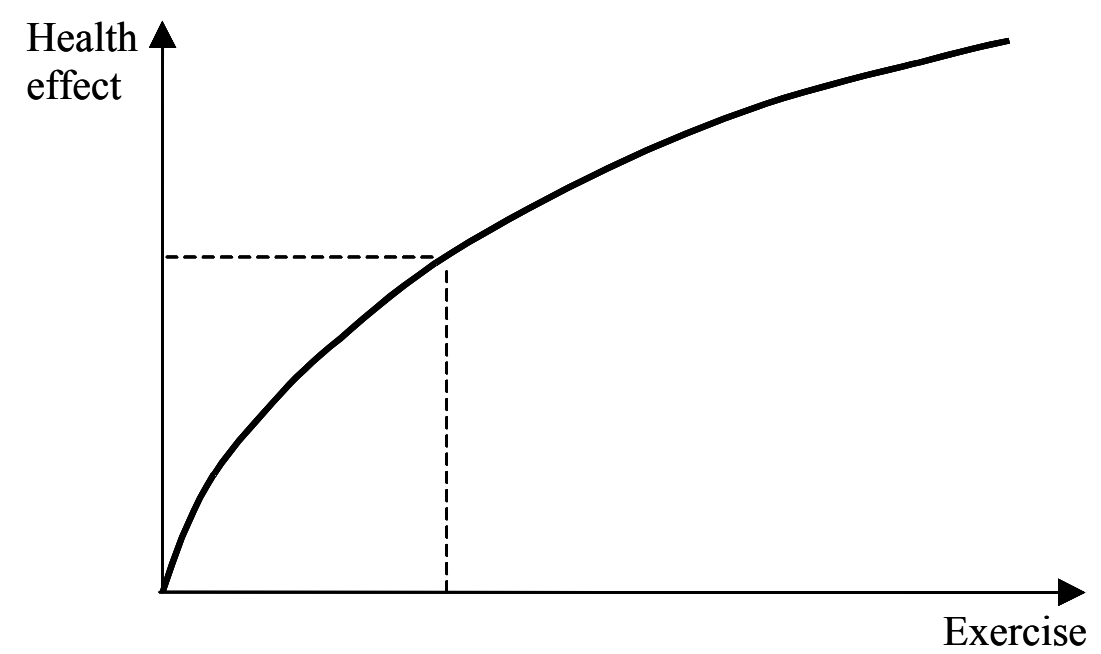

Cycling reduces a variety of diseases. A large Danish study has shown that people who take their bicycle to work have a $28 \%$ lower mortality rate than the average population (after adjustment for, among other issues, differences in terms of job, smoking, leisure-time activities, and body mass index). There is solid Danish evidence that physical exercise reduces the risk of developing the following diseases: heart attacks, diabetes 2, osteoporosis, colorectal and breast cancer, as well as high blood pressure. International research also indicates that depressions, backpains, and strokes can be reduced significantly. By following the exercise recommendations, one can diminish the risk of these diseases by 30 to 50 $\%$. Thereby, one has not only a longer life in store, but can also look forward to more years in good health. If you ask road users themselves, those who cycle feel in better physical and mental shape than those who do not cycle.

Cycling can meet exercise recommendations. Cycling meets the above mentioned exercise recommendations - in the same way or even better than brisk walking - if a speed of approximately $20 \mathrm{~km} / \mathrm{h}$ is maintained, or (if cycling at a slower pace) if hills, stops, or headwind are involved.

Air pollution. Measured by time an average cyclist breathes less polluted air than an average car passenger. During rush hours, when pollution and congestion are the highest, average car speed is pretty much the same as the average cycling speed, and cyclists will therefore be less exposed to pollution. This is different, however, when cycling outside of rush hours. In this case, cyclists do travel at a lower speed than cars, but the level of pollution is correspondingly lower. Moreover, very few cyclists will cycle the same distance as the distance covered by most cars.

Bicycle accidents. Many people believe that it is more dangerous to cycle than to drive a car. Measured in accidents per $\mathrm{km}$ this is a fact, but 
measured in time cycling is only a little more dangerous. The risk of fatal accidents is related inversely to the number of cyclists. For example, the risk of getting killed on your bicycle is 4 times higher (measured as deadly accidents per million kilometres) in France than in Denmark, where there is 10 times as much bicycle traffic as in France. This tendency is strengthened by an active effort to make the roads safer to cyclists. Between 1990 and 2000, for example, Copenhagen has successfully reduced the number of injured cyclists per year by $25 \%$ (definite numbers). In the same decade the cycle traffic was increased by $40 \%$.

Reducing the speed of cars has had a good effect on creating safer roads. Likewise, creating more cycle paths has good effects on safety. Completely separate cycle paths have not been an unconditional success. These paths cause problems in some cities, since some cyclists will ignore the paths and instead choose shorter or less desolate roads that are no longer suitable for cycling. Safety campaigns can also be of great importance. Research shows that the risk of accidents is counterbalanced to a great extent by the positive effect of cycling on physical health.

\subsubsection{Cost-benefit analyses of cycling}

Norway, Finland, Switzerland, Great Britain and Canada, have all carried out cost-benefit calculations of physical exercise in general or increased cycling in particular. In these analyses, the large-scale economical benefits of health improvements have been of special interest. The Nordic Council of Ministers is also preparing a similar analysis. These analyses all speak the same language: when all relevant factors, including the effect on national health, are taken into account, investment in cycling turns out to be very profitable. Health has so far - until the present report - not been taken into account in any Danish economical analysis of traffic. Analyses of traffic projects have only focused on private and public motor vehicle transportation, and have thus ignored the possible consequences such projects might have for pedestrians and bicyclists.

There is a lack of official figures for walking and cycling in the Ministry of Transport's manual for socio-economic analysis. The associated catalogue of key values (user costs, taxes, time costs, external costs, etc.) contains no figures for walking and cycling, and consequently no figure for health effects either.

Health considerations. The official recommendation in Denmark is half an hour of exercise per day. This has been interpreted as 183 hours activity per year (e.g. walking or cycling). If this is achieved, then the probable outcome is a $40-50 \%$ reduction of risk for several diseases (cardiovascular, cancer, diabetes, muscle/skeletal, back pain, depression). 
To analyze effects on health is a complicated task. One can add up the expenses saved in the health sector and the benefits of fewer days of absence due to illness. But it is harder to put a price on a lower mortality rate, and one may question whether it is morally or ethically justifiable to attempt to do so. However, such estimations are already made in the above-mentioned economical analyses of investments in car roads and public transportation.

No separate Danish figure has been derived, but the health benefits will probably be similar to figures abroad:

- 564 Euro (Switzerland, Brian Martin et. al, 2001) = $3.09 € /$ hour

- 980 Euro (Norway, TØI, 2002) = $5.37 € / \mathrm{h}$

- 738 Euro (UK/Harry Rutter, statistical value of life, unpublished)

$$
=4.04 € / \mathrm{h}
$$

In the Danish calculations, the value $4.7 €$ /hour is used. A reduction factor is also applied as not all exercise leads to health benefits. It is further assumed that the public benefit is $40 \%$ and the individual user benefit is $60 \%$.

External costs. No reduction in accident costs are assumed in the Danish calculations as the basis for the quantification is too uncertain. External costs for car are assumed to be in the magnitude of $0.05 €$ per personkm.

Other specific assumptions. It is assumed that the behavioural changes towards cycling will take some time. The full benefit will therefore not arise until 12 years after the investment. A linear assumption is made during the transformation period. A generalised cost-elasticity of -1.0 is assumed for cycling and walking.

The interest rate is assumed to be $6 \%$. The 'wrenching' loss when transferring money from the private to the public sector is assumed to be $20 \%$ and the taxation (VAT) factor is assumed to be 1.17 .

\subsubsection{Example of results}

The Danish Ministry of Transport's manual on socio-economic analyses has been used to investigate the economical consequences of large-scale investment in cycle-initiatives. The study supposes a funding of 150 million DKK (20.3 million Euros) every year, over a period of 12 years presupposing that this will stimulate the inhabitants of cities with a population exceeding 5,000 to cycle as much as the people in Copenhagen do. However, the study experienced difficulties in getting Danish figures concerning potential economical benefits of increased physical activity. We therefore chose to use figures from other countries. A provisional calculation indicates, however, that Danish figures would be of roughly the same size. Investments in cycle-initiatives turn out to have a very 
good profit and cost-benefit ratio, much better, in fact, than what one would normally expect from economical analyses of traffic projects.

The result seen over a 50 years timescale is a net present value of 23 billion DKK (3.1 billion Euros), a benefit cost relation of 1.35 and an internal rate of return of $66 \%$, which means very positive. The health improvements alone have a net present value of 20 billion DKK (2.7 billion Euros). The results of the calculations are quite robust against changes of the assumptions behind the calculations. So in spite of substantial uncertainties concerning the involved parameters, the result is strikingly positive.

Surprisingly the projects' impact on public expenses due to reduced taxrevenue on cars and fuel and reduced revenue from public transport fares

$$
\begin{array}{rr}
\text { present value } & \text { full annual effect } \\
\text { (mill. Euro) } & \text { (mill. Euro) }
\end{array}
$$

\section{Public expenses}

Initial investment in infrastructure

$-167$

Maintenance of infrastructure

Promotion and information

Public share of health effects

Tax yield

$-659$

Income for public transport

$-2,475$

Remaining value of infrastructure

User benefits

3,703

External costs

Health benefits for users

Wrenching loss

are much higher than the investment in bicycle infrastructure and campaigning.

The results are robust towards changes of direct investment in bicycle infrastructure and campaigning and the effects from this, while the value of the health and consumer advantages has a larger influence, together with the relationship between car, public transport, walking, and bicycling.

\subsubsection{Conclusions and further research}

In light of the Danish analyses it is recommended that:

- Danish calculations must be made of the economical benefits of increasing physical exercise, including cycling.

- Health effects (total value, public share), transfer conditions ( $\mathrm{km}$ walk/bike/public transport/ car) and time costs including cost- 
elasticity for walking and cycling (to obtain benefits) should be investigated further.

\subsection{Valuing the mortality benefits of regular cycling}

\section{Harry Rutter, University of Oxford, United Kingdom}

\subsubsection{Approach}

In the Nordic countries, the health effects of cycling have been derived from longitudinal studies of activated persons in certain risk groups. In United Kingdom a different approach has been undertaken, based on cross-sectional data of regular commuters.

Obesity is a far more important problem in Britain than in the Nordic countries. Twenty percent of the population suffers from obesity compared to 5-10 percent in the Nordic countries ${ }^{3}$. A study has therefore been undertaken to estimate the probable benefits of increased cycling.

\section{Obesity}

$\%$ of population * with Body Mass Index over 30 , latest year available

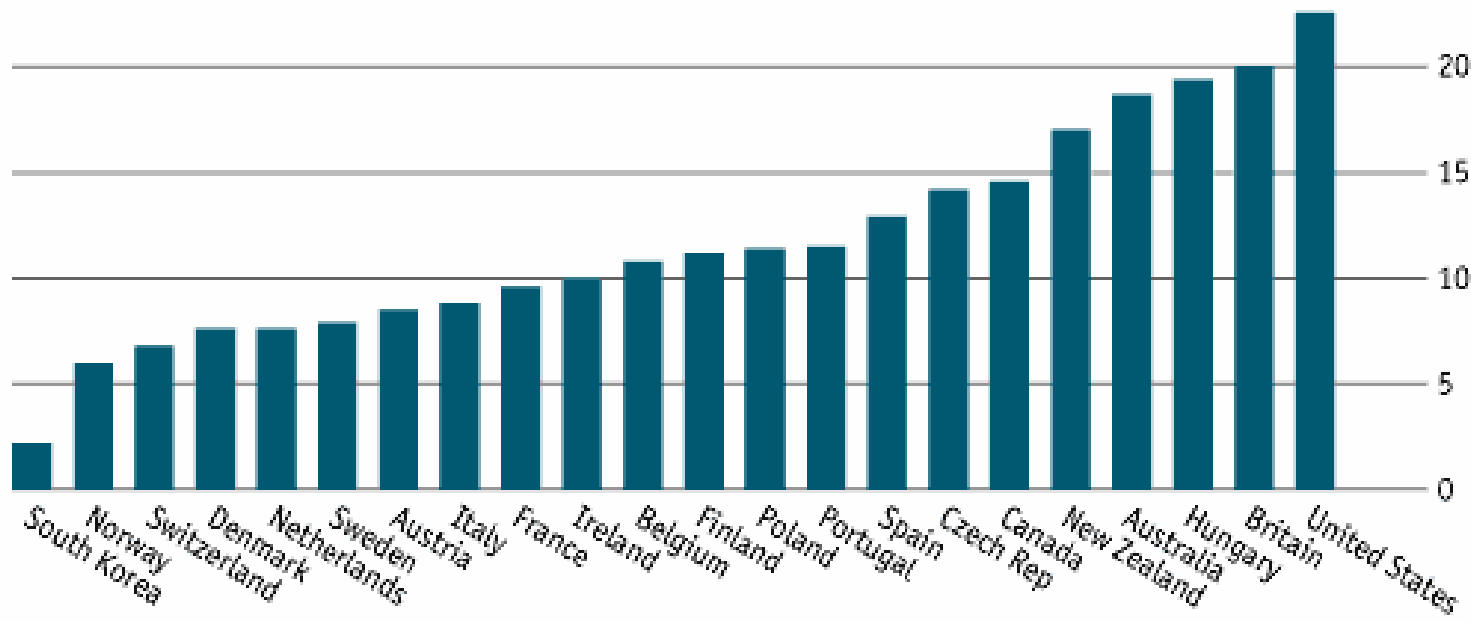

The British approach can be summarised:

- Based on Copenhagen heart study data

- Impacts related to UK

- Cyclist deaths included in model

\footnotetext{
${ }^{3}$ The latest Swedish figure is $10 \%$ according to Folkhälsoinstitutet.
} 
- Life years gained/lost calculated

- Value of life year applied to LYG figure

- Value of annual mortality benefit per cyclist obtained

Based on a study of Paffenberger et al (1986), we can derive the relationship between minutes of cycling per day and relative risk of death. It seems that the relative risk is halved when cycling two hours per day. Daily commuting 30 minutes to and from work might reduce the risk with $25 \%$. These results are confirmed by the Copenhagen heart study.

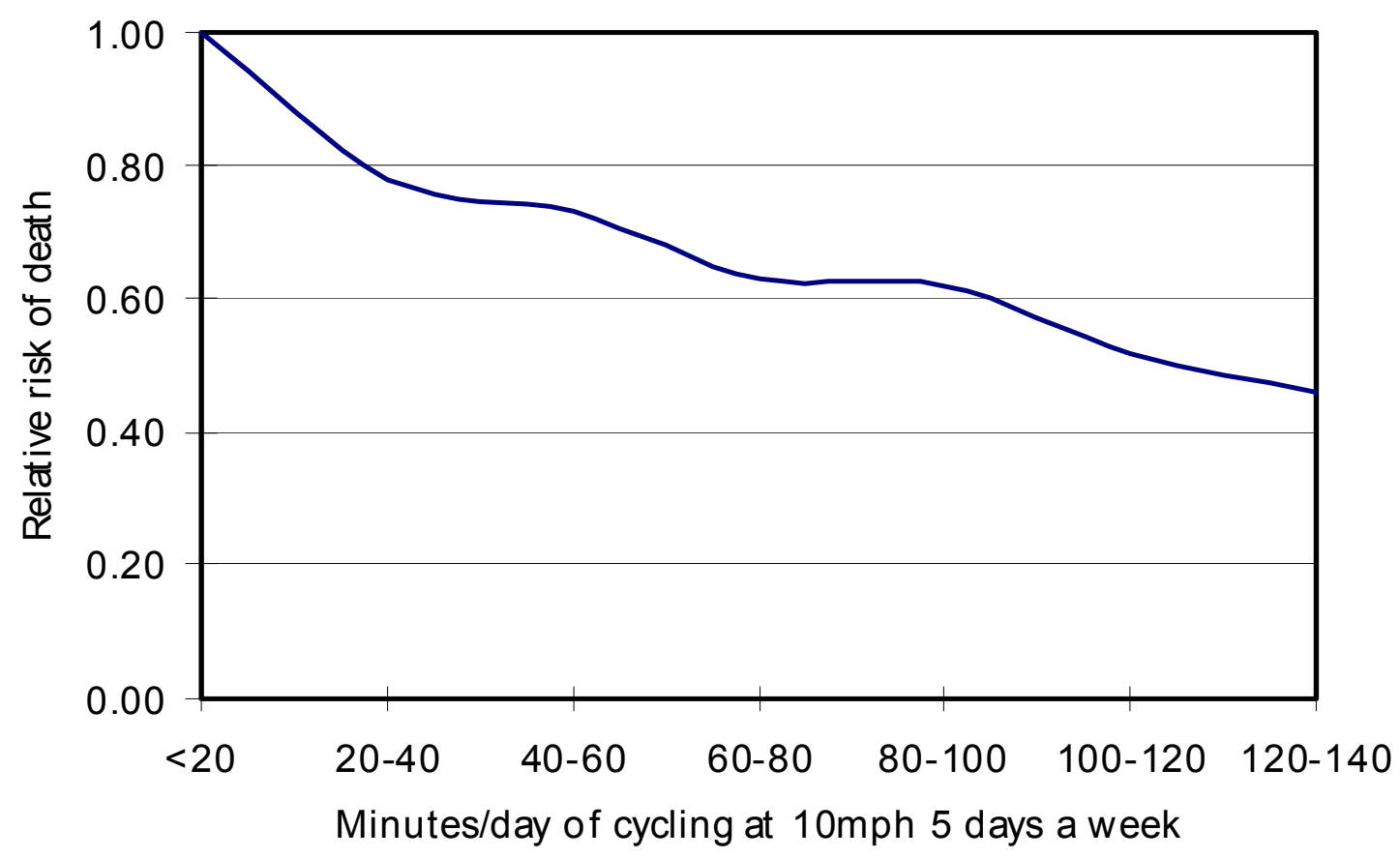

\subsubsection{Cycling accidents}

A common question is if more cycling leads to more accidents among cyclists. There were no serious cyclist injuries recorded in the Copenhagen heart study. It seems from studies of Californian and European cities that a growing share of cyclists and pedestrians result in a reduced risk for serious accidents involving unprotected road users. When the cyclist flow is high, there is a tendency that car drivers care more about the unprotected road users. 


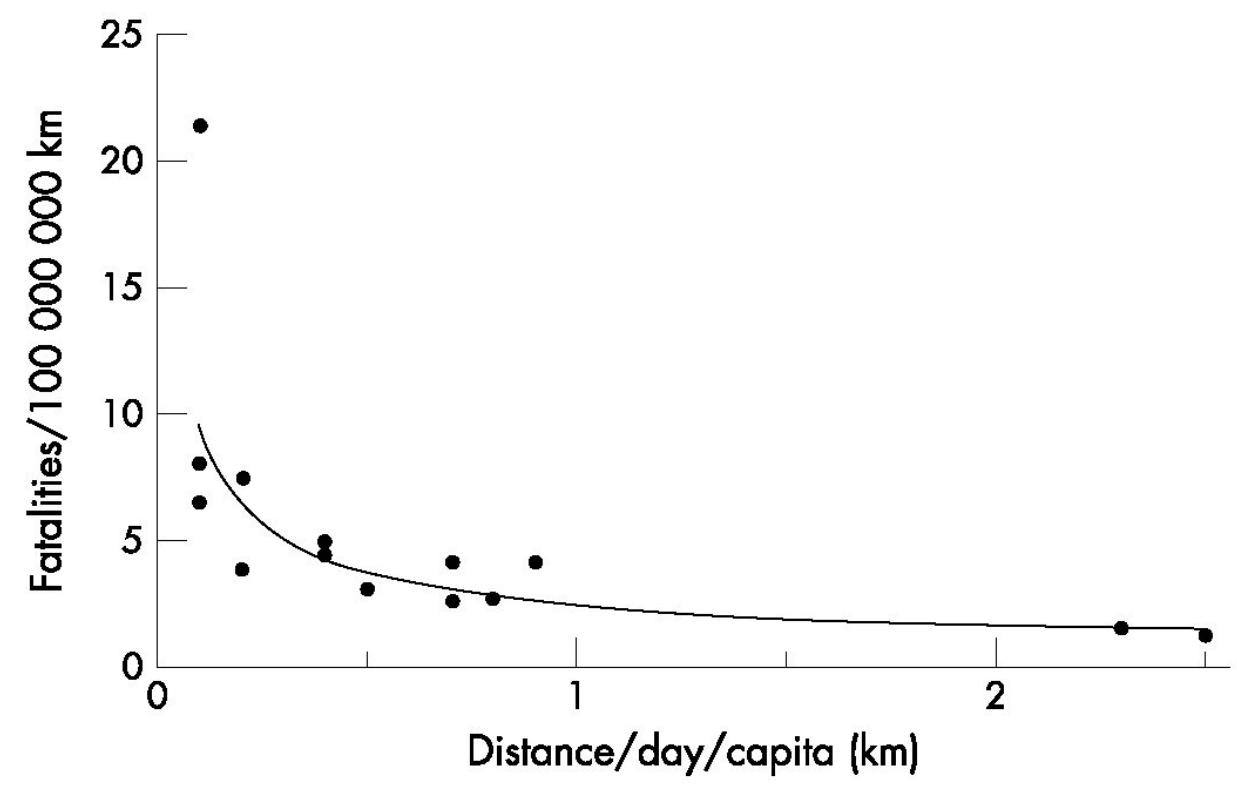

This possible reduction in risk has not been taken into account in the calculations below of the number of excess deaths among cyclists.

\subsubsection{Calculations for UK}

Cycling is a healthy and sustainable mode of transport that allows people to build physical activity into their daily lives without harming others or the environment. Fear of the perceived danger of cycling is a major disincentive to many people. But the true risks of cycling are low, and the health benefits greatly outweigh the health costs. There is one cyclist death per 34 million $\mathrm{km}$ cycled, and there is a ratio of around 20:1 in terms of life years gained by cyclists as a result of the health benefits compared to those lost by cyclists killed on the roads. People who cycle an average of 3 hours a week (such as a daily commute of around 6 kilometres each way) have a risk of dying $28 \%$ lower than the general population.

If 100,000 people, evenly spread between the ages of 20 and 60 , were to take up regular cycle commuting this would result in 57 fewer deaths in any one year among those cyclists (Rutter, 2005). However, 7 would die on the roads because of cycling. This gives a net benefit of 50 lives saved, which is equivalent to around 1660 life years. If we assume a value of around $£ 30,000$ per life year ${ }^{4}$ this results in a net benefit, purely in terms of mortality, of just over $£ 50$ million from those 100,000 cyclists. $^{5}$

\footnotetext{
${ }^{4}$ Based on the 40 life years lost for a cyclist death, and the Department for Transport cost per life of $£ 1.25$ million, the cost per life year is $£ 31,250$

${ }^{5}$ These figures are based on conservative estimates. The Copenhagen data include cyclist deaths on the roads, so this risk is double-counted. There is also good evidence that increases in cycling (and
} 
An extensive study of cycle commuters has been made in Copenhagen (Andersen et al, 2000). The Copenhagen heart study included 6,954 regular cycle commuters out of a total study population of 30,640 , followed up for an average of 14.5 years. The mean journey time for the cycle commuters was 3 hours per week. The relative risk of death for the cycle commuter cohort was $0.72\left(95 \% \mathrm{CI}^{6} 0.57-0.91\right)$ after adjustment for age, sex, educational status, leisure time physical activity, body mass index, blood lipid levels, smoking and blood pressure.

The British calculations assume that people cycle for 3 hours a week as in the Copenhagen heart study. It is also assumed that injuries increase linearly with increased cycling. A scenario with 100000 additional cyclists is analysed.

\section{Number of people taking up cycling in this case study}

\section{Number of deaths averted due to health bene- fits of cycling}

Mean proportion of population aged 20-60 dying/year

Deaths from all causes expected in 100000 people aged 20-60

Deaths averted because of cycle commuter RR of 0.72

\section{Number of excess deaths among cyclists}

Extra distance cycled per person - $12 \mathrm{~km} /$ day for 220 days/year at $20 \mathrm{~km} /$ hour (i.e. 3 hours/week)

Total extra $\mathrm{km}$ cycled by the 100,000 extra cyclists

Risk of death per km cycled (mean from 19941998)

Extra cyclist deaths

\footnotetext{
${ }^{6}$ Confidence interval
} 


\section{Reduction in deaths and gain in life years}

Mean age of death of non-cyclists (1994-1998) 48

Mean $\mathrm{LYL}^{7}$ for a non cyclist death 34

$\mathrm{LYG}^{8}$ through deaths averted $\quad 1954$

Mean age of death of cyclists (1994-1998) 41

Mean LYL for a cyclist death $\quad 40$

294

LYL through cyclist deaths

Net reduction in deaths $\quad 50$

$\begin{array}{ll}\text { Net gain in life years } & 1660\end{array}$

Values associated with these data

Value of a life year

Benefit per cyclist

This case study has focused solely on the impacts of increased cycling on mortality among regular cyclists such as cycle commuters. This is because the evidence for these health benefits is robust and quantifiable, and because an accurately quantifiable health outcome was felt to be desirable.

\subsubsection{Conclusions and further research}

The following conclusions can be drawn from the British study:

- Cycle commuting is a healthy activity

- Even in the relatively dangerous road environment in Britain the benefits far outweigh the costs

These calculations only consider mortality benefits - inclusion of wider impacts would demonstrate a greater benefit, but result in wider confidence intervals.

\subsection{Discussions on methodological aspects}

This section is based on the discussions during the Nordic seminar on the $1^{\text {st }}$ February, 2005.

\footnotetext{
${ }^{7}$ Life years lost

${ }^{8}$ Life years gained
} 


\subsubsection{What effects should be included in CBA of cycling?}

The participants seem to agree that the following effects should be included in a CBA of cycling:

- Comfort and security

- Public health benefits (treatment costs, loss of production, welfare benefits)

- Reduction of external costs (maintenance, emissions, noise, accidents etc) for motorised transports

- Consequences for public transport

- Costs of cycling

- Effects on transport of school children

- Accidents for cyclists and other road users

- Travel time

Comfort and security are estimated from stated and revealed preferences studies in the Swedish approach. All countries agree that this approach is appropriate. The same fundamental approach is made in Denmark. In Norway, only the insecurity costs were included in the study, but in principle also other types of comfort should be included. In Finland, comfort and security was not included in the Turku study, but there is no theoretical objection.

Public health benefits are important in all countries. Differences occur when it comes to how these shall be calculated, see discussion below.

Reduction of external costs (infrastructure, congestion, emissions, noise, accidents etc) for motorised transports should also be included in CBA for cycling. In Norway accidents cost are excluded as the number of injury accidents is assumed not to be affected by substitution of motorised transport by cycling and walking. In Sweden, congestion costs are not included. In Finland, congestion costs are treated as a separate effect. In Denmark, the same approach has been used as in Norway. Accident costs have been assumed to be close to zero.

All countries also agree that reduced parking costs caused by transfer from road transport to cycling should be included. The Norwegian approach is adopted in the other Nordic countries. In Sweden, these are, however, included in the external costs.

Public transport is treated separately in the Finnish guidelines and the Danish case study. Operating costs and ticket revenues as part of the change in producer surplus are included in the CBA. These effects are not included in Norway and Sweden, but there is no objection to do that in principle. 
The cost of cycling (investment, insurance, maintenance) is included in the Swedish study, but not in the other countries. There is, however, agreement that it is correct to include this effect.

Effects on transport of school children are included in the Norwegian study. The same approach is adopted in Finland. This effect is not included in the Swedish and Danish study, but there is no objection, if it can be quantified.

Road accidents are only quantified in the Swedish study. A difference in the Swedish study is that it is made for a specific cycle corridor into a city centre. In the other Nordic countries, the studies are made more on a strategic level where it is harder to recognize and calculate the effect on road accidents. In principle, these effects should be taken into account. These are, however, set to zero in the Norwegian, Finnish and Danish study.

Almost the same is valid for travel time. It is only quantified in the Swedish study, but there is no objection to include it, if it is possible to calculate.

\subsubsection{Taxation effects}

The taxation effects are treated somewhat differently in the Nordic countries. There are two types of effects.

The first is a factor corresponding to the average VAT rate that is added to cost components in order to have all effects measured in a common consumer-oriented scale. Results from WTP studies, investment, maintenance etc will then be comparable. The second factor is a distortion or transfer factor, which is introduced to take into account the loss in efficiency by transferring money from the private sector to the public sector.

There seems to be a common view in the Nordic countries, although the second factor not is included in the Norwegian and Finnish case studies. Both factors are united into one single factor in the Swedish guidelines. The current Swedish factor is 1.52. Infrastructure costs are multiplied with this factor in CBA's in the public sector. The second factor is called 'wrenching loss' in Denmark and assumed to be $20 \%$. The VAT factor is assumed to be 1.17 .

\subsubsection{Are there other possible factors to include?}

Candidate effects mentioned in the discussion that can be included in CBA of cycling if they are evident and possible to quantify are:

- Comfort changes in Public transport 
- Air pollution, climate gases

- Land use, impediments

- Urban quality

- Aesthetics

- Visual intrusion

- Encroachment

To a certain degree, these effects are included in comfort, consequences for Public transport, external effects etc. but some aspects may be further developed to be fully covered. It is however more important to improve the basis of quantification for the direct effects of cycling in the first place.

\subsubsection{Change in demand}

Estimation of the changes in demand from cycling initiatives is crucial in order to compile a CBA of cycling. In the Norwegian study the following assumptions were made:

- Walking and cycle track networks provide $20 \%$ (5-40\% in sensitivity analyses) induced walking and cycle journeys. (Induced walking and cycle journeys mean journeys that would not have taken place without the new networks and not journeys that today are made using other modes of transport.)

- $15 \%$ of current journeys less than $5 \mathrm{~km}$ made by car or public transport are replaced by walking or cycling.

- Among current journeys by car or public transport that in the future are replaced by walking or cycling, about $1 / 3$ are replaced by walking and $2 / 3$ by cycling.

It is further assumed that completion of the existing cycle path network will result in these effects. No direct link between measures and change in demand is established, this is a rough estimation on the strategic level. The costs for this completion are calculated. A similar approach has been adopted also in Finland.

In the Swedish study, the change in demand is estimated based mainly on a few stated preferences studies and only one revealed preferences (actual behaviour) study. A direct link between measures and change in demand is established, but the evidence is weak. The resulting travel time elasticity is estimated to -0.1 . This means that a reduction of cycling travel time with $10 \%$ will result in a $1 \%$ increase in cycling trips.

In the Danish case study, it is assumed that the generalised cost (time, comfort, health etc) elasticity is -1.0 for cycling and walking.

According to the discussion, it can be concluded that it is necessary to establish a reliable link between measures for improving the cycling 
network and the actual change in demand that such efforts have resulted in. The problem is that too few studies are made and convincing evidence is therefore not at hand today.

An interesting question is the importance of scale and the interaction with restrictions for car use. Freiburg is an example where the city centre is not designed for cars. There are incentives to use other means than cars and there exist no external shopping centres.

Single pieces of cycle paths can not change a lot. It is necessary to take the systems approach. In Odense, there are a lot of restrictions that were introduced together with the cycle network. The change in cycling of $11 \%$ is therefore not just a result of improving the cycle infrastructure. We must get more insight in elasticities of cycling, both travel time and generalised cost elasticities. The figures -0.1 for travel time in the Swedish study and -1.0 for generalised cost in the Danish study are not in accordance with each other.

\subsubsection{Health benefits}

Health benefits include both public expenses/savings for hospital and other public paid treatment costs as well as private expenses/savings, production loss from illness and welfare benefits from a longer lifetime. In order to deduce the relationship between bicycle measures and medical costs, we must run through several mental steps. Bicycle measures lead to more cycling, more cycling leads to fewer inactive persons and decrease in obesity, decrease in inactivity and obesity lead to decrease in medical costs and excess morbidity. 

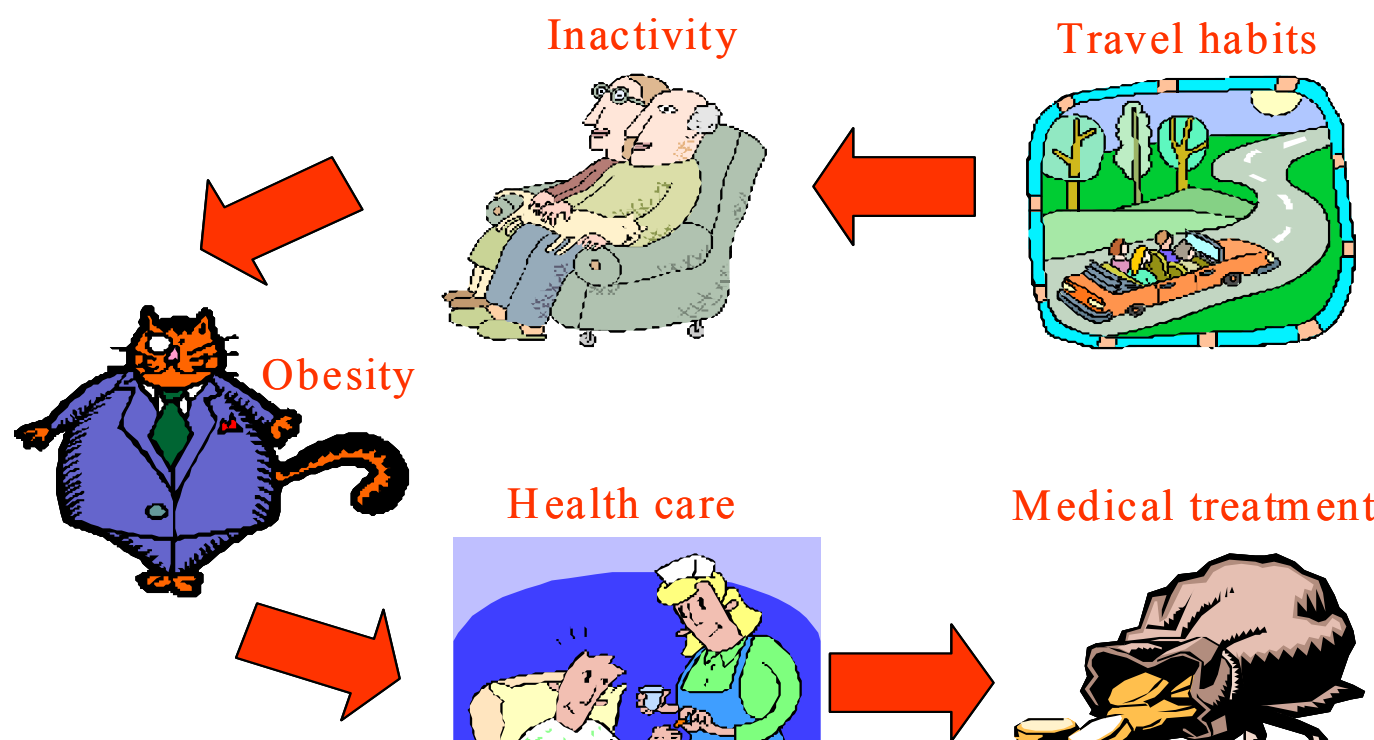

Health care

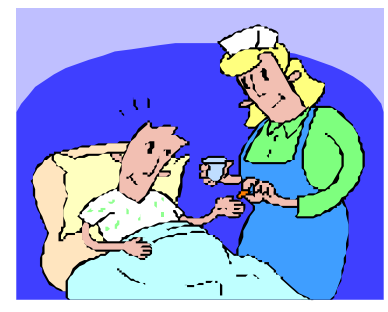

Medical treatment costs

There seems to be fairly good consensus about the health effects of activating inactive persons. Three different approaches have landed in figures in the same magnitude. Saelensminde has calculated a value for Norway of NOK $7300 \approx 880 €$ per person and year who becomes "moderately more physical active". Persson has calculated a value for Sweden of SEK $8600 \approx 940 €$ for activated elderly people and an average value of 2600 SEK $\approx 280 €$ per generated cyclist, including also formerly active cyclists. Rutter has calculated a value for UK of $£ 498 \approx 740 €$ per activated cyclist.

The longitudinal studies in Britain based on the Copenhagen heart study and the studies based on medical evidence seem to give fairly the same result. It was concluded that we never will get better studies than the US DPP and follow-up studies used in the Swedish calculation.

The differences we can observe, lies in the dose/response relationship. We must build up knowledge about who are starting to cycle and why. Marketing strategies must be developed on how to reach inactive elderly people. In Finland, Denmark, Sweden and UK it is stated that the minimum dose of cycling to get the health effects is at least 30 minutes per day. This observation has been included in the case studies in various ways in order to get a realistic estimation of the health effects of more cycling.

An idea that came up in the discussion is to make an attempt to use the other countries framework and see what differences that will occur. We should be able to make a spread sheet where every country can include its own available figures but use default values for other factors. It seems 
important to put the framework into practice. An objective must be to reach consensus on a pan-European level in the long run.

\subsubsection{Comfort}

The discussion lead to the conclusion that there is consensus of using comfort values in CBA for cycling. It is of great value that this type of studies has been made in Sweden. Comfort values have earlier only been published in the WALCYNG project. More studies are necessary to get more reliable values. A reflection that was made is that there are different kinds of cyclists. Long-distance cyclists do not want any stops at all. Elderly and children need security and safe intersections.

It is important to define comfort and what it stands for in order not to double-count the impacts of cycling measures. A question that can be raised is if WTP studies are disadvantageous for poor people. The traditional way to solve this dilemma is to use average values for all travellers in the CBA.

\subsubsection{Road safety}

There is wide consensus that road safety should be included in CBA for cycling. It is quite important that we try to quantify the safety effect and the possible negative effects of cycling.

There is a lot of knowledge about road safety. The most comprehensive source is the Norwegian Traffic Safety Handbook. In order to quantify the effects properly, a classification of the cycle environment in safety classes can be helpful. As the necessary information not was available, safety effects were assumed to be zero in the Norwegian, Finnish and Danish studies.

\subsubsection{Valuation}

Different approaches have been made to estimate the value of time for cycling in the Nordic countries. In Sweden a value of SEK $90 \quad 10 €$ is assumed for cycling in mixed traffic and SEK $70 \quad 8 €$ on a cycle road. The difference is due to better comfort and security on a cycle road.

In Denmark a value corresponding to $66 \%$ of the value for motorised transport is used based on the Norwegian TØI analysis. In the case study a value of DKK $35 \quad 4.5 €$ is used. These values are lower than in the Swedish study. The reason for using a higher value in Sweden is that cycling for most people not cycling are somewhat more inconvenient than other means of transport. Also in Norway, a value for cycling is adopted that is higher that for motorists. The reason for using a lower value in WALCYNG is that cycling is more used for leisure trips and trips or short duration for those already cycling. 
If we, however, are discussing the same trip distance, it is probable that people already cycling have a lower value than people that can be convinced to start cycling. Different values might therefore be appropriate for current cyclists and transferred cyclists form motorised transport.

A new valuation study is planned in Norway for car drivers, Public transport passengers and cyclist. In Denmark, a new valuation study is completed by TETRAPLAN for car drivers and Public transport passengers. Unfortunately, cyclists were not included in the study.

Values used in the different approaches to CBA of cycling in the Nordic countries are summarised in the table below:

\begin{tabular}{|c|c|c|c|c|}
\hline EFFECT & $\begin{array}{c}\text { NORWAY } \\
\text { Saelensminde }\end{array}$ & $\begin{array}{l}\text { SWEDEN } \\
\text { Lind et al }\end{array}$ & $\begin{array}{c}\text { FINLAND } \\
\text { Metsäranta, Tervonen }\end{array}$ & $\begin{array}{c}\text { DENMARK } \\
\text { Krag et al }\end{array}$ \\
\hline Comfort & No value & $\begin{array}{l}\text { SEK 0-20 per trip or SEK 0-5 } \\
\text { per cyclekm }\end{array}$ & $\begin{array}{l}\text { Partly included in health } \\
\text { benefits (accessibility) and } \\
\text { external effects (noise). }\end{array}$ & $\begin{array}{l}€ 0.06 \text { per cyclekm (user } \\
\text { benefits) }\end{array}$ \\
\hline Insecurity & NOK 2 per cyclekm & Value included in comfort & No value & No value \\
\hline $\begin{array}{l}\text { Public health } \\
\text { benefits }\end{array}$ & $\begin{array}{l}\text { NOK } 7300 \text { per year (activated } \\
\text { person) }\end{array}$ & $\begin{array}{l}\text { SEK } 12000 \text { per year } \\
\text { (activated person aged 50-60 } \\
\text { years) }\end{array}$ & $\begin{array}{l}€ 1200 \text { per year (activated } \\
\text { person) }\end{array}$ & $\begin{array}{l}\text { DKK } 2760 \text { per year (activated } \\
\text { persons) or } € 2.35 \text { per } \\
\text { cyclehour (additional trips) }\end{array}$ \\
\hline $\begin{array}{l}\text { Short-term } \\
\text { absence }\end{array}$ & $\begin{array}{l}\text { NOK } 2500 \text { per year (employed } \\
\text { activated person) }\end{array}$ & No value & $\begin{array}{l}\text { Value included in health } \\
\text { benefits }\end{array}$ & $\begin{array}{l}\text { Value included in health } \\
\text { benefits }\end{array}$ \\
\hline External costs & $\begin{array}{l}\text { NOK 0.4-1.4 per vkm } \\
\text { (reduced car traffic) }\end{array}$ & $\begin{array}{l}\text { SEK } 0.45 \text { per vkm (reduced } \\
\text { car traffic) }\end{array}$ & $\begin{array}{l}€ 0.009-0.02 \text { per vkm (reduced } \\
\text { emissions), } € 10.6 \text { per vh } \\
\text { (reduced congestion). As } \\
\text { regards possible reduction of } \\
\text { noise emissions, value of } € 959 \\
\text { is used for persons subjected } \\
\text { to noise levels above } 55 \mathrm{~dB} \text {. }\end{array}$ & $\begin{array}{l}€ 0.05 \text { per personkm (reduced } \\
\text { car traffic) }\end{array}$ \\
\hline Public transport & No value & No value & $\begin{array}{l}€ 1.8-3 \text { per trip (reduced } \\
\text { income) }\end{array}$ & $\begin{array}{l}\text { DKK } 2 \text { per personkm } \\
\text { (reduced income) }\end{array}$ \\
\hline Cost of cycling & No value & SEK 0.6 per cyclekm & No value & $€ 0.05$ per cyclekm \\
\hline School children & $\begin{array}{l}3.90 \text { NOK per childkm } \\
\text { (reduction in school bus } \\
\text { transport) }\end{array}$ & No value & No value & No value \\
\hline Accidents & No value & $\begin{array}{l}\text { MSEK 0.8-1.8 per injury } \\
\text { accident }\end{array}$ & $\begin{array}{l}€ 84000 \text { per accident. } \\
\text { The calculated value of } \\
\text { human life is } € 1934000 \text { (used } \\
\text { when evaluating fatal } \\
\text { accidents) }\end{array}$ & No value \\
\hline
\end{tabular}

It was concluded at the seminar that it is important to get to a consensus of the valuation of time for cyclists as well as comfort values. An idea that came up was to further discuss a common study in the Nordic Group for Sustainable Development. 



\section{Policy relevance}

\subsection{National Cycling Strategy in Norway - Making Cycling Safe and Attractive}

\section{Gyda Grendsted, Statens vegvesen, Norway}

\subsubsection{The Storting has called for a national cycling strategy}

During the Storting's debate on 7 June 2001 the Government was asked to formulate a national cycling strategy aimed at making it safer and more attractive to use a bicycle as a mode of transport. The Storting requested that such a national cycling strategy be incorporated into the national transport plan.

The strategy was drafted by the Norwegian Public Roads Administration in cooperation with the Directorate of Health and Social Affairs, the Norwegian Association of Local and Regional Authorities and the Norwegian National Cycling Association (Statens vegvesen, 2003).

\subsubsection{The goal of a national cycling strategy}

The goal of a national cycling strategy is to make it safer and more attractive to cycle. These intermediate goals have been set:

- The risk of fatalities or permanent injuries from road accidents is not to be higher for a cyclist than for a motorist.

- The share of bicycle traffic in "bicycle towns" (towns opting to facilitate cycling) is to increase by $50 \%$.

- Bicycle traffic in Norway is to comprise at least $8 \%$ of all travel (out of the total number of trips).

Today the risk of death or permanent injury is three times as high for cyclists as for drivers, calculated per kilometre. The goal of sharply increasing bicycle use gives bicycles an important role in the transport system.

\subsubsection{Why should more people cycle?}

Health. Regular physical activity protects against premature death and the emergence of cardiovascular disease, high blood pressure, type-2 diabetes, excess weight, obesity and several cancers. Physical activity 
also improves one's mental health and is important for preventing muscle, skeletal and joint ailments. Recent research shows that less physical activity are required than previously assumed to achieve a significant health gain. For inactive adults, physical activity of moderate intensity equivalent to a 30-minute brisk walk every day will yield substantial benefits.

Physical inactivity can be isolated as an independent risk factor for a number of illnesses and ailments, and in industrial countries only smoking constitutes a greater risk than physical inactivity. There are reasons to assume that about half of the adult population is not sufficiently physically active. An average weight gain among 40-year-old men of $9 \mathrm{~kg}$ in the past 40 years points in that direction.

Environment. In the largest urban areas, it is important to focus on cycling, mass transit and walking as a strategy for achieving greener transport. In the other cities and towns, the focus is on cycling and walking, which are the keys to achieving greener transport. The bicycle's range is long enough to make it a suitable alternative to the car for short trips.

Socio-economic benefits. It is good socio-economics to facilitate more cycling. The Institute of Transport Economics has calculated that investments in a continuous cycle path network will yield a net benefit of over three times the cost for the three towns studied, Hokksund, Hamar and Trondheim. This is a very favourable beneficial effect compared with other transport investments.

Lower absenteeism along with reduced costs, for instance, for parking and transport to school, constitutes a saving of up to NOK 30,000 a year for every sedentary person who becomes a cyclist. For society this means a daily saving of NOK 150 for each new bicycle commuter. This calculation is based on expenditures on traffic accidents remaining constant compared with the current situation, and assumes that the main cycle path network is fully developed.

\subsubsection{Greatest potential for increased cycling in cities and towns}

In Norway, $4 \%$ of all trips are by bicycle. In most other European countries this share is $5-10 \%$, with the Netherlands on top, with $28 \%$ of all trips by bicycle. In Sweden, the share is $12 \%$, and there is a goal to increase this to $16 \%$ by 2010 .

The Institute of Transport Economics has calculated the bicycle potential of Norwegian cities and towns. The potential for increased cycling is found primarily in the area of short car trips. Half of all trips are shorter than $5 \mathrm{~km}$. It is calculated that there is a potential for increase foot and cycle traffic by $50 \%$ in cities and towns with over 5,000 inhabitants. 


\subsubsection{Making it safer and more attractive to cycle}

The goal to increase bicycle use can only be reached by a concerted focus on infrastructure, so that, for instance

- cycling feels safe by individuals; parents especially need to feel that their children are safe while cycling to and from school

- by cycling a person follows the shortest route and comes closer to his destination than by car

- cycle traffic is given priority over or is on an equal footing with cars on public roads and streets and in crossings.

- accessibility and parking for bicycles is given priority at shopping centres and public transit nodes.

This will require a wide spectrum of measures where the Ministry of Transport and Communications, the Norwegian Public Roads Administration, counties, municipalities, companies and relevant interest groups are key players. Additionally, a basic assumption is that expertise in planning for bicycle use be enhanced.

Vision Zero for traffic safety is a vision of no fatalities or permanent injuries in road traffic. The national cycling strategy is based on this vision. The traffic rules need to be improved so that they help to make it safe and attractive to cycle, while cyclists must be influenced to follow these rules. Safety standards must be set for bicycles, and cyclists must wear a helmet and readily visible clothing and use reflectors.

Cycling in cities and towns. The efforts in cities and towns are aimed at planning continuous main cycle path networks, including facilities for parking bicycles. Extensive use of bicycles will only be achieved if bicycles have advantages over other modes of transport. This means that all measures that make it less attractive to drive will make it more attractive to cycle or take public transport. Restrictive measures on car traffic, such as road pricing and parking restrictions, will thus have a positive impact on cycling as well as on walking and public transport use. Such measures should presumably be in addition to improved infrastructure if cycling is to increase substantially.

Planning a continuous cycle path network starts with inspections of cycle paths. Reports on the subject provide good suggestions for further planning and for improvements in the way of immediate measures.

Handbook 233 - Sykkelhåndboka - Utforming of sykkelanlegg (The Cycling Handbook - Designing Bicycle Facilities) provides guidance in planning main cycle networks in cities and towns. One recommendation is to provide more separation between foot and cycle paths in high-traffic areas. Among solutions that are new or little used we would like to mention experiments with cycling against vehicle traffic on one-way streets and marking and signposting dedicated cycle lanes. 
"Bicycle accounts" can provide data on status and on implemented measures. Documentation or description takes the form of key figures. At the same time, such bicycle accounts must inform cyclists - and others about current plans, what is being done in the area and the initiatives taken afterwards? Bicycle accounts must be revised regularly (for instance, every other year), so that changes/improvements can be documented.

In all, we estimate the central government's responsibility for new construction and rebuilding in a continuous cycle path network in cities and towns with over 5,000 inhabitants to be $800 \mathrm{~km}$. Assuming a price per running metre of NOK 10,000 yields an investment need in the order of NOK 8 billion.

Cycling along the national highway network. Building separate foot and cycle paths along the national highway network began early in the $1970 \mathrm{~s}$, with a total of $3,000 \mathrm{~km}$ now built.

The need remains for a further $1,850 \mathrm{~km}$ of foot and cycle paths along the national highway network. Assuming a price per running metre of NOK 5,000 yields an investment need in the order of NOK 10 billion. In choosing solutions, wider hard shoulders are acceptable as stopgap measures.

Maintenance. Cyclists are a type of road user that is extra sensitive to uneven roadways, mud splashing and poor surface quality. The booklet "Vedlikeholdsnormer i et sykkelperspektiv" (Maintenance standards from a bicycle's perspective), issued by the Norwegian Association of Municipal Engineers in August 2001, introduced the concept "user-optimal standard". These standards describe conditions that are important to cyclists. Although the introduction of "user-optimal" standards will make maintenance more costly, much of the impact can be attained by devoting more attention to a clean and even road surface and to signposting and marking.

Combining cycling and public transport. Policy aims should be secure bicycle parking at relevant transport stops and building safe cycle links between built-up areas and such stops. In 10 minutes a cyclist covers a distance of 3,200 metres as opposed to 800 metres for a pedestrian. Such a quadrupling in distance yields a sixteen-fold increase in the area a transit stop serves.

In a number of situations people want to take their bicycles along on public transport. Schemes are needed to make this possible, such as contracts permitting bicycles to be taken along on buses, passenger ferries, trams/trains and aircraft. For modes of transport with rush-hour peaks, this will have to apply outside of rush hour. 
Employers need to encourage cycling in connection with work. Concrete examples of employer encouragement will be exercise and shower facilities, remuneration for bicycle use in connection with work, secure bicycle parking and subsidies for purchasing a bicycle.

Leisure and holiday cycling encourages everyday cycling. Leisure cycling comprises $2 / 3$ of all bicycle journeys. Facilitating leisure time bicycle use is primarily a local responsibility, since this involves measures in residential or other neighbourhood areas. It involves cycling for fun and to run errands, bicycle trips in the countryside and cycling for sport.

A survey conducted in 2001 showed that more and more Norwegians wish to go on cycling holidays in their own country, and that cycling holidays are one of the leading forms of active holiday in Norway.

The regulations need to encourage cycling. The responsibility for administering the relevant legislation has been delegated on various levels and among several ministries. An ongoing evaluation of the legislation can ensure that the laws are modified in step with societal developments. The main document contains recommendations relating to cycling that merit consideration.

Increased knowledge and expertise. If bicycles are to assume a greater share of the public transport burden, we need to know more about what must be done to get people to cycle instead of drive. Since the mid-1970s the Norwegian Public Roads Administration has been registering the "number of kilometres of foot and cycle paths", but there is a need for reporting that tells us more about the quality of facilities for cyclists.

In connection with planning for increased bicycle use, it is important to preserve the expertise of users. In Norway, the Norwegian National Cycling Association represents the top user expertise relating to bicycle traffic and cycling.

Information and motivation. Comprehensive and targeted marketing measures must be implemented aimed at safe and attractive cycling. The message on the national level needs to be followed up and amplified by a wide array of local activities. National media campaigns should be followed up and amplified by activities locally and in a network of "bicycle towns". 


\subsection{CBA's role in Swedish Planning}

\section{Patrik Arousell, Swedish National Road Administration, Sweden}

\subsubsection{Introduction}

Generally, in order to try to define what role CBA may have in relation to public infrastructure investments in cycling, something has to be written about the planning structure for the same and then, by the defined structure, relate the role of CBA to it. The purpose of the following "paper" is then to give a brief outline of the structure for public planning in Sweden, mainly at the municipal and state level. The outline will then serve as a base for a discussion on the role CBA may have in planning and in particular for decisions related to infrastructure investments in cycling (Arousell, 2005).

In Sweden, the three main public sector planning authorities related to road infrastructure are the Municipality (Kommunen), the County (Länsstyrelsen) and the Parliament (Riksdagen). Two of these actors, the Municipality and Parliament (and their executive instruments, the committee's and Ministries), may be defined as the main actors relating to issues concerning bicycling, while the county mainly plans for infrastructure investments in roads for motor traffic (excluding light motorcycles etc). Therefore, the following text will examine the decision process for the two main actors, the State and the Municipality, and its executives.

\subsubsection{Planning for Goals}

There are four main types of "planning" documents in Sweden that form the basis for goals within bicycle infrastructure investments. These documents are:

- The bill Transportation Policy Toward a Sustainable Development (prop. 1997/98:56) where the main goal for national transport policy and subsidiary goals are defined

- The 15 national environmental targets, which have been defined by Parliament in the bill Swedish Environmental Targets. Environmental Policy Toward a Sustainable Development (prop 1997/98:145)

- The United Nations Convention of Children's Rights

- The health goal as defined by the World Health Organisation

The main goals for what bicycle infrastructure investments should achieve may then be concluded from these documents. Infrastructure investment related to bicycling may then be seen as an instrument by 
which the goals within these documents will be achieved (to a certain degree).

\subsubsection{Bicycling in the State}

Basically, there are four major actors within the national public administration in Sweden, Parliament, the Government and its executives, the Ministries and Public Authorities.

Government and Parliament have on several occasions expressed a will to improve conditions for cycling. The Government bill Transportation Policy toward a Sustainable Development, includes:

“.. a long term sustainable transportation system should, among other things, include an increasing share of cycling within urban areas. But, the risk with an increase in bicycling is a potential increase in injuries. This is not compatible with the aims of Vision Zero or society's striving to achieve a long-term sustainable transportation system. Therefore, risk of death or injury should be managed by reducing speeds in mixed traffic in urban areas, a separation of car, pedestrian, and bicycle traffic and a striving towards an increased use of bicycle helmets."

Among the public authorities, the main stakeholders are the Swedish Road Administration, the Swedish Environmental Protection Agency, and the National Board of Housing. The interpretation made by the Swedish Road Administration related to its sector responsibility within the road transport system, and related to cycling is; in order to achieve the goals to increase the number of cyclists and improve safety, a broad assembly has to be summoned. The main strategy has then been to form a dialog with other partners within the sector. Among these, the Swedish Association of Local Authorities and Regions, the Swedish Environmental Protection Agency, the Swedish National Board of Housing, the county Boards and the National Institute for Public Health may be mentioned as central contributors in the work.

Related to planning at a State level, the four previously mentioned documents could be seen as guidelines for the role of infrastructure investments in bicycling. In its work related to sector responsibility for cycling, the Swedish Road Administration and its partners have in a working group suggested a strategy in order to implement bicycling as a complement or substitute to other forms of travel.

Related to the bill, Transportation Policy toward a Sustainable Development, (prop 1997/98:56), the group has concluded that the main subsidiary goals which are affected in the national strategy of bicycling are related to the subsidiary goals of accessibility, safety and environment. 
The national environmental targets have also been reviewed, as stated in the bill Swedish Environmental Targets. Environmental Policy Toward a Sustainable Development (prop 1997/98:145). Within it, the proposed strategy to achieve the targets is related to measures to reduce environmental disruptions from transport and measures which will result in a more environmental friendly development within society. The working group has concluded that if cycling increases, a number of the environmental targets will be achieved, not least the goals related to fresh air, a well constructed environment, and limited impact on the climate.

According to the working group, several of the WHO's health goals may be achieved if an increase can be seen in cycling, not least the goals related to the health of young people, a reduction in non-contagious diseases, reduced injuries from violence and accidents, a safe environment, and more healthy living.

\subsection{4 $\ldots$ and within the Municipalities}

The most disaggregated level of planning within the state in Sweden is achieved at the municipal level. The municipalities within Sweden have the right of self governance implemented in the Swedish constitution where self governance implies that, within certain limitations, each municipality has the right to make decisions without restrictions from central authorities. According to Swedish "Municipal Legislation", the municipalities have a right to maintain services related to public benefits within the boundaries of the municipality and in general, may not maintain services which the state, other municipalities or counties are responsible for.

Related to the goals within the municipalities with investment in bicycle lanes, nothing substantially differs from the previously defined goals, but at municipal level planning is closer to the actual implementation than at a national level.

Comprehensive Plan. The Comprehensive Plan is the planning document for the built environment within the municipality in the long-term and the planning document at the highest aggregated level. The planning document may fulfil three important functions within the municipality:

1. It may be used as a vision for the municipality's progress in the future

2. It is an instrument which simplifies and makes daily decisions within the municipality more efficient

3. It is an instrument in communication between the state and the municipality in accordance with the public interest

The Comprehensive Plan then provides the intentions for the built environment within the municipality in the long-term. The Comprehensive 
Plan is also the planning document which provides planning conditions within the municipality at the highest aggregated level.

Not surprisingly, nothing explicit is expressed in the Comprehensive Plan concerning bicycle infrastructure investment. However, most Municipal Comprehensive Plans relate to bicycle infrastructure investments, where these investments are seen as an instrument to achieve the defined goals for the municipality.

Detailed Development Plan. The Detailed Development Plan is an instrument for the municipality to achieve its local building policy and social ambitions. At the same time, it should promote an economic and rational building construction business. The Detailed Development Plan should review the use of public space, water areas and block ground and define the borders of the same.

As for the Comprehensive Plan, nothing explicitly is mentioned_about bicycling within the Comprehensive Plan but the Detailed Development Plan provides the overall framework within which infrastructure investments related to bicycling should be made. All analyses related to investments in infrastructure for bicycling should, therefore, have this planning document in mind.

\subsubsection{CBA, does it have a Role in Planning?}

The conclusion from the above text is that the national goals for bicycling do not differ from municipal goals, despite the fact that the municipalities have a large degree of self determination. The implication then is that the prerequisites exist for cooperation between national and municipal authorities to develop methodology to evaluate the benefits of bicycle infrastructure investments.

In the planning process for infrastructure investments, and then related to bicycling on a national level, the previously mentioned four programmes have been seen as guidelines for goals to be achieved through investment. The mentioned working group has then come to the conclusion that, in order to achieve the intended goals, two major objectives have to be achieved by infrastructure investment related to bicycling:

- Bicycling should be safer

- Bicycling share of the total traffic volume should increase

Given positive results toward the fulfilment of these goals, the other goals will then automatically be reached. But these goals may be seen as goals on a highly aggregated level and in practice they can be hard to plan for. This brings us to the question of the role of the municipalities. 
For the municipalities, the question of the role of a CBA ought to be discussed related to the goals and planning instruments within the municipalities. Given defined goals, a CBA could be used to answer the question what instrument should be used to achieve the goals, where bicycling is one among several. But in order to be able to do this at a municipal level, several questions have to be solved related to the effects of an investment in bicycle infrastructure.

Related to the municipality's main planning document, the Comprehensive Plan and the Detailed Development Plan, nothing is at hand which invalidates CBA as a tool to be used in planning for the built environment within the municipality. Related to the planning process within the municipality, it seems that CBA could provide input to the Detailed Development Plan and thus, it should be used late in the process. What may be challenging to achieve in order to implement the CBA as a tool in municipal planning is to create a flexible method which is easy to use but still takes account of all variables of interest.

The difference between the municipal and national level is that the goals have been stated at different aggregation levels. In practice, the main goal for the Swedish Road Administration has been to reduce the number of injuries, with bicycle investments as an instrument. At a municipal level, the goal has been to increase the number of cyclists. This implies that national and local level interest uses different variables when they use CBA as a tool to evaluate the efficiency of bicycling infrastructure investments. The interests are not mutually exclusive but complement each other and thus, ought to be merged within the same methodology.

Related to variables of interest within the CBA, the goals to be achieved with infrastructure investments in bicycling as an instrument has briefly been reviewed. The goals mainly relate to the questions of health, security and the environment and within the CBA, the variables of interest to be included within the analysis ought to be variables which relate to the fulfilment of the goals.

Related to the role which the Swedish Road Administration could have in this setting, it may be related to the overall responsibility for the transportation sector. This could imply that the Swedish Road Administration ought to have a responsibility to provide tools for the municipalities and other parties to enable evaluations of cycle infrastructure investments. Thus, the Swedish Road Administration ought to contribute to finance the development of the methodology. 


\subsection{Cycling policy in Finland and relevance of CBA}

\section{Risto Saari, Ministry of Transport and Communication, Finland}

\subsubsection{First national Cycling Policy Programme}

The first Finnish National Cycling Policy Programme was adopted in 1993 (Saari, 2005). The main objectives in the programme were:

- Duplication of the cycling performance by year 2000 .

- Halving the number of fatal cycling accidents by year 2000

The programme presented 85 measures how these objectives could be reached. The programme contained also a rough programme level impact assessment on the effects of doubling cycling performance. The annual investment costs needed wereas estimated to be around 100-150 million euros. The assessment showed that most of the investment costs should be received back already with the improvements in traffic safety. Other additional national health benefits were estimated to be around 6070 million euros. Net benefits of duplication of cycling performance were estimated to exceed the investment costs by some 100-200 million euros per year. (All estimates in currency/price level of year 1993).

Municipalities and the Finnish Road Administration are in charge of cycling network investments. Even though the cycling policy programme had clearly shown that the benefits of improved cycling networks, this had no direct effect on the local level investment decisions nor the project level CBA evaluations for roads. One of the main reasons was the economic recession in early years of 1990's and the municpalities and the Finnish Road Administration were not able to increase funding in cycling networks.

Nevertheless, some progress was achieved even with limited increase in resources. The Finnish Road Administration and some of the municipalities presented the main cycling networks containing also planned cycling investments. The planned cycling investments were listed as a kind of ranking list from which cycling network investments were implemented when resources were available. Usually it was traffic safety consideration that effected on prioritisation of cycling projects. Also initiatives and presseru coming from individual citizens, village or suburban committees sped up implementation of certain cycling investment plans.

A follow-up report of the first national Cycling Programme was presented in 1999/2000. It was stated that the influence of the programme had been more political impact than economic impact. The main result of the first cycling programme was that cycling had become an important 
and integrated part of transport policy, transport planning and transport system. Cycling policy had also been integrated more closely to other transport policy programmes and strategies. The status of cycling had increased, but not that much of funding as expected to cycling netwok investments. The other results of the programme can be summarised as:

- The number of cycle trips had slightly increased (1992 around 0,93 million passenger kilometres, 1999 1,6 million passenger kilometres).

- Number of fatal cycling accidents had been halved (1990: 101 killed 2000: 53 killed in fatal accidents)

- Improvement of cycling network and marking of routes

- National cycling network/cycling tourist map.

- Other services: Cycling police, cycling pilots etc. services, bike rental, cycling storage, weekly cycling tours and trips, selection of cyclist of the year, cycling campaigns and marketing.

Despite the very ambitious objective, the reduction of fatal cycle accident by $50 \%$ was achieved. The positive development has continued and in year 2004 there was 25 fatal cycling accidents.

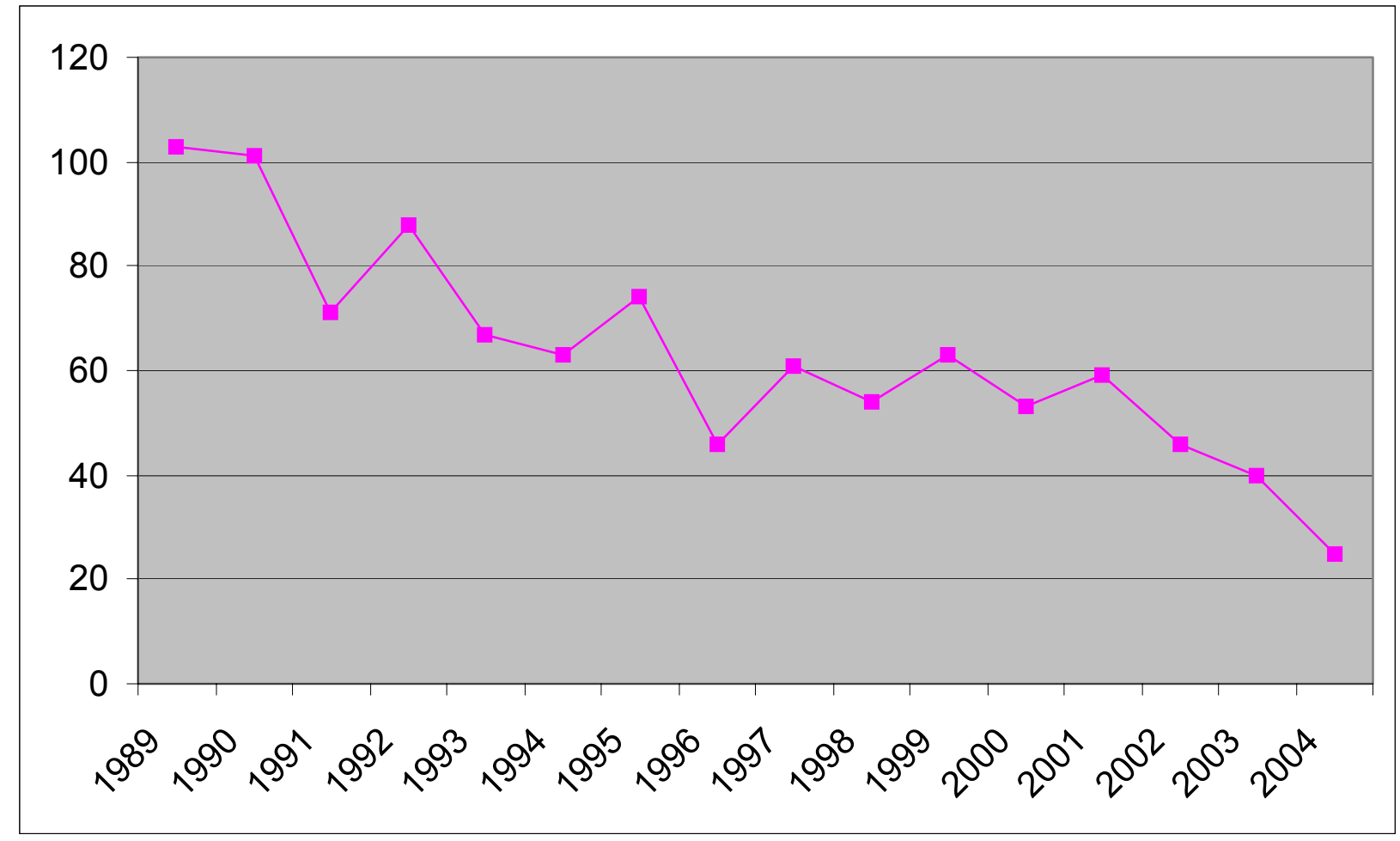

Figure: Fatal cycling accidents in Finland between 1989-2004

The figure shows that between 1989-2004 number of cycling accidents have been reduced by some $75 \%$ in Finland. Even though there has been improvement in traffic safety in general (all fatal traffic accidents have 
been reduced by some $50 \%$ at the same time), the main concrete result of the cycling promotion work in Finland has been that the number of cycling accidents has been managed to reduce dramatically at the same time when cycling performance has slightly increased.

\subsubsection{Second Cycling Policy Programme}

The second Finnish National Cycling Policy Programme was presented in 2001. It was prepared in close conjunction with the National Walking Policy Programme and National Public Transport Strategy. The overall objective was the promotion of all sustainable modes of transport and increasing their attractiveness and thereby maintaining and even increasing their market share. The programme contained the following qualitative and quantitative targets:

Qualitative targets:

- Improvements in the quality, attractiveness and safety of cycling.

- Increased weight on it in transport policy decisions.

- Cycling should be more competitive vis à vis the private car and should be combinable smoothly and safely with the use of public transport.

$\bullet$

Quantitative targets:

- Safety should improve in the long term in accordance with the general road safety targets.

- The amount of cycling should have doubled by the year 2020 relative to the 1998-99 level. The level in 1998-99 was $4 \%$ of trips and $2 \%$ of person kilometres.

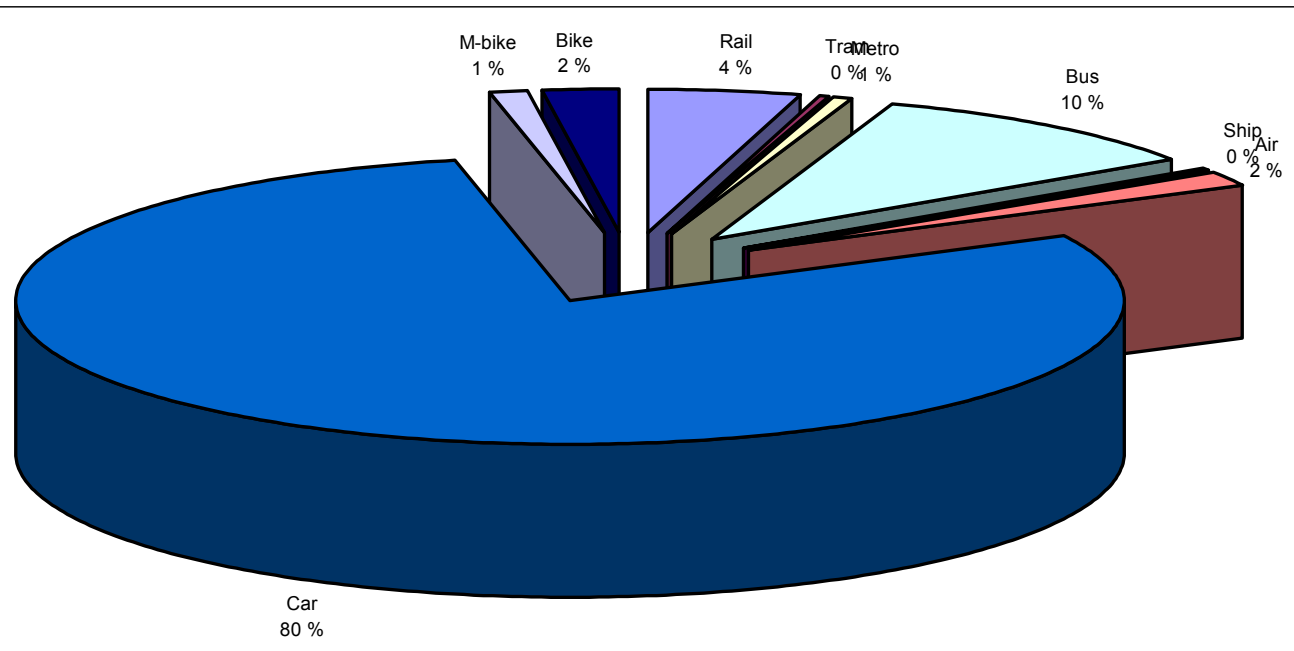


The second programme did not contain an overall assessment of costs and benefits. The general framework (see Chapter 2.3) for project level CBA analysis had however been developed in the meantime.

The development started in the early 1990's when developing the general framework for transport infrastructure investment evaluations (roads, railways and airports). As mentioned in Chapter 2.3, the so-called YHTALI-framework "Evaluation of Social and Economic Effects of Transport Infrastructure Investments" was adopted in 1994. In 2004, the Ministry of Tranport and Communications presented new "unit value indexes" that should be used by the Finnish Road Administration and other agencies when evaluating their transport infrastructure investments and their feasibility.

The Finnish Road Administration and other agencies (Finnish Rail Administration, Finnish Maritime Administration and Finnish Civil Aviation Administration) now evaluate all infrastructure projects on the basis of similar cost-benefit evaluations. Projects are listed in accordance with cost-benefit evaluations, but political prioritisation may change the results of CBA evaluations.

Questions have been raised how to deal with cycling and other environmental investment projects? Basically the general CBA framework developed is applicable also for cycling and walking. It can be noticed that time savings received have an important role in CBA calculations for infrastructure investments (within the YHTALI-framework). This leads to prioritisation of big road investment projects. Municipalities decide however independently on their investment projects and whether they use CBA calculations.

The need was recognised for more detailed guidance on CBA evaluation of cycling and walking investments. This has lead to the Guidebook published in 2004 includinggeneral health aspects based on the Norwegian study and the recognisation of the need for national data.

\subsubsection{Other ongoing activities}

The promotion of cycling has continued in a very pragmatic way after adoption of the second cycling programme in 2004. Instead of adopting any Government Resolution or any other Ministerial Decision on promotion of cycling, several concrete projects were inititiated. Experimental projects (so-called JALOIN-project, meaning on the one hand "By foot/On your own" and on the other hand "the Noblest") are carried out in municipalities to promote sustainable modes of transportation. Another activity is co-financed investment projects at the local level in the context of so-called regional and local level transport system plans. These transport system plans provide a tool for Government to participate in the development of local urban transport system planning and thereby pro- 
vide funding for promotion of cycling, walking and public transport investments.

In the current research programme for cycling and walking around 20 research reports were produced by May 2003. One of them was the CBA analysis reported earlier. A new research and development programme is under preparation. The main emphasis will be improving statistical data basis and increasing knowledge on health and other social effects.

Parallel activities that also should be mentioned:

- Cycling helmet use is obligatory but not punished in Finland since 2002.

- Cycling centres are established in conjuction with travel centres.

- Efforts are made to integrate cycling into the concept of Mobility Management.

\subsubsection{Conclusions}

The following conclusions have been drawn concerning the future action plan:

- Determined and long-standing planning is needed

- National and government level support is needed for local and regional level activities.

- Active co-operation between transport, environment, health and other authorities, is crucial both at the national and local level.

- Integration of cycling policy into the other transport policy objectives (such as transport system planning, public transport, zoning, mobility management, accessibility strategy, traffic safety and environmental management of transport policy).

- Quantification of health and other social and environmental effects is needed.

- Guidance for municipalities and Road Administration is needed in order to avoid overestimation/underestimation of certain aspects in CBA.

- More statistical data and monitoring are needed.

- Tools for forecasting and modelling are needed.

- Benchmarking with other countries. 


\subsection{Cycling, Environment, Exercise and Health}

\section{Thomas Krag, Mobility Advice, Denmark}

\subsubsection{Background}

A new strategy for cycling is presented in "Cycling, Environment, Exercise and Health", a report from the Danish Ecological Council (supported by the Danish Health Agency and the Rockwool-foundation) this year (Det økologiske råd, 2005). The main objectives in the strategy:

- A third of short trips should be transferred to walking and cycling

- Less safety hazard when biking

"Cycling is a convenient and enjoyable form of exercise ...Yet its benefits to health and the environment are frequently overlooked ...The British Medical Association highlights the significant contribution cycling can make to the nation's health and calls for radical changes in current transport policy".

Source: Cycling Towards Health and Safety, British Medical Association, 1993

More cycling would enhance the health of the Danish population. Today, $15 \%$ of the trips are made by bicycle in Denmark. Around 60 fatal cycling accidents occur each year. An average cycle trip is made over a distance of $3 \mathrm{~km}$. There is, however, a general downward trend for cycling according to the figure below:

\section{Index for bicycle and car traffic}

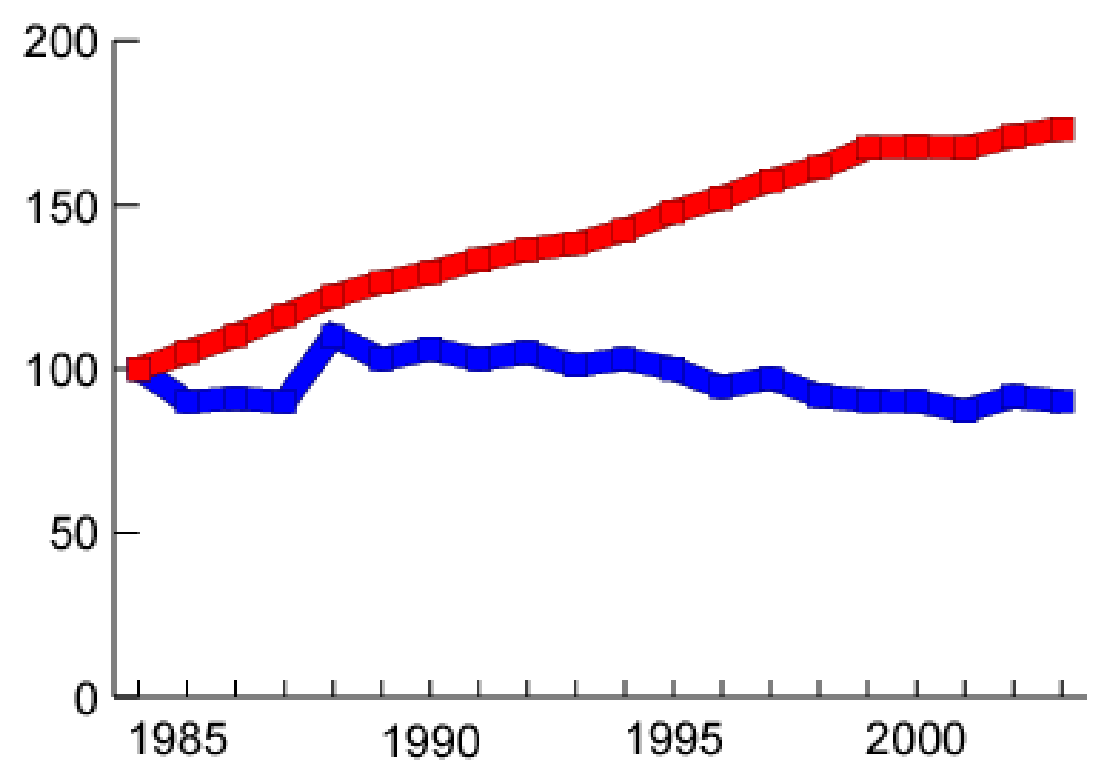


The negative trend is not valid all over Denmark. Positive trends can be found in Odense and Copenhagen. Odense (urban population: 170,000) achieved the following aims over a four year period with an investment of 0.7 mill. Euro extra per year:

- $20 \%$ increase in cycling (when compensated for adverse effects)

- $20 \%$ less cycling injuries

Copenhagen experienced an increase of cycling by $40 \%$ and $27 \%$ less cycling injuries over 10 years with an additional investment of 3 mills.

\section{Cycle traffic in Copenhagen}

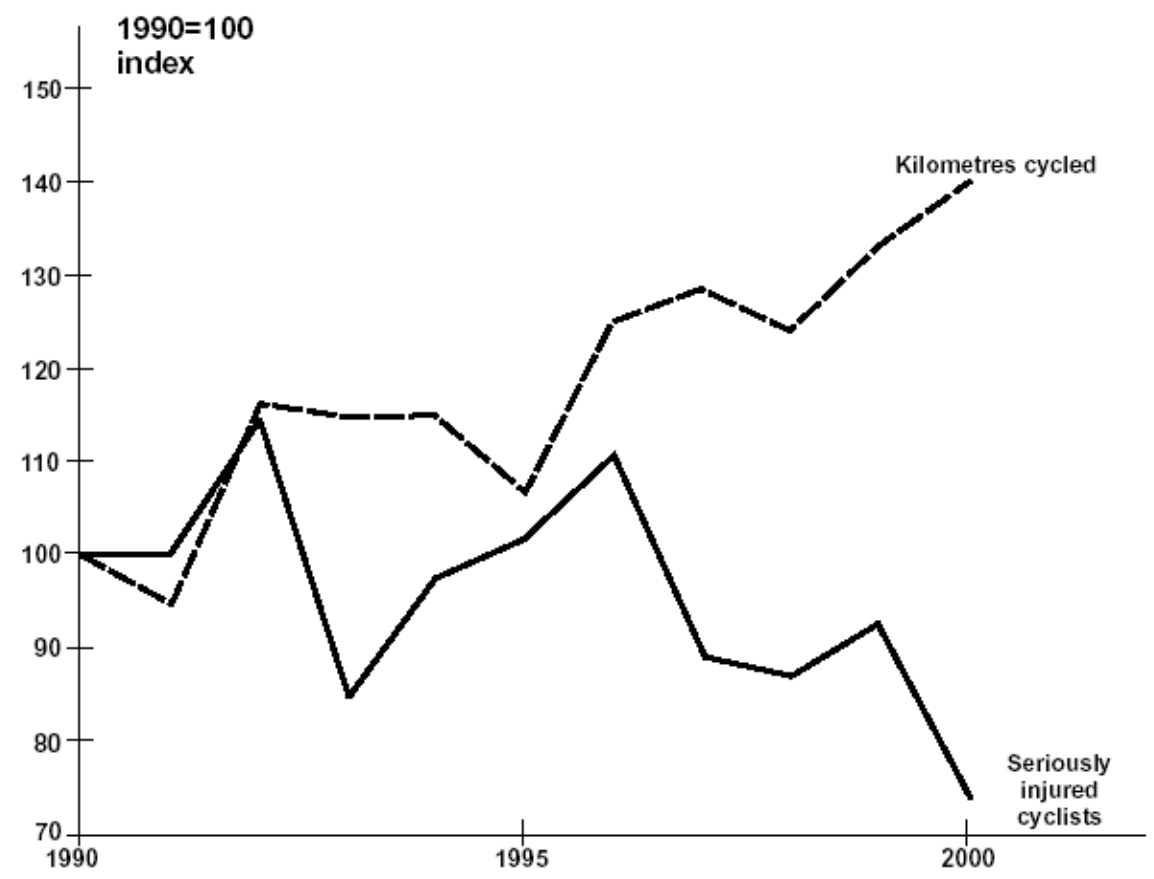

Euro per year.

\subsubsection{What prevents people from cycling?}

Many people claim that they would cycle more if conditions for cycling were better. Most of the people who do not cycle find the distance to and from work too far, say that cycling would take too much time, that they have too much to carry, and that the weather often is too bad. Others point out that there are too few cycle paths or that the existing paths are in poor condition. However, when they actually try it out, many find that cycling is less time consuming than they believed it would be, and that it rains less than they thought. Research shows that people in households with one car very rarely use their bicycle. If there is more than one car in the household people cycle even less. Many of those that do cycle give 
the reason that cycling provides good exercise and considerable freedom of movement.

Younger people express the same reservations as grownups, although theft is also a very important issue for the former. Few adults consider risk of accidents a reason for not using a bicycle. But accidents play an important role in adults' deliberations about whether to allow their children to cycle. When they are asked, many children say they prefer to cycle to school rather than be taken by car.

Campaigns urging children to cycle more can have great effect. As many as 70,000 children took part in the school campaign "All Children Cycle" organized in 2003 by the Danish Cycle Federation. Of this number 15,000 children where "new" cyclists, and after the campaign had ended 5,000 children continued to use their bicycle.

There is a great difference in cycling between town with 2,000-10,000 inhabitants with 0.9 cycling $\mathrm{km}$ per person per day and Copenhagen and Frederiksberg with 2.5 cycling $\mathrm{km}$ per day. This fact has been used to calculate the potential for more cycling in Denmark based on two assumptions:

- Cycling in towns from size 5,000 and up (2.7 million people) increased to Copenhagen level

- Part of the short motorised trips transferred to cycling.

This calculation results in 900 million kilometres more cycling per year among people aged 10-84 years (current level: 1,778 million kilometres per year, e.g. an expected $50 \%$ increase).

\begin{tabular}{|l|c|c|c|c|c|}
\hline Trip length & $\begin{array}{c}\text { number of car, } \\
\text { train and bus } \\
\text { trips } \\
(1,000 \text { per day) }\end{array}$ & $\begin{array}{c}\text { average } \\
\text { trip } \\
\text { length } \\
(\mathrm{km})\end{array}$ & $\begin{array}{c}\text { transport } \\
\text { (mio km per } \\
\text { year) }\end{array}$ & $\begin{array}{c}\text { proportion } \\
\text { assumed } \\
\text { transferred to } \\
\text { bicycle }\end{array}$ & $\begin{array}{c}\text { transport } \\
\text { transferred to } \\
\text { bicycle } \\
\text { (mio km per year) }\end{array}$ \\
\hline $1-2 \mathrm{~km}$ & 1,127 & 1.5 & 617 & $33 \%$ & 204 \\
\hline $3-4 \mathrm{~km}$ & 1,038 & 3.5 & 1,326 & $25 \%$ & 332 \\
\hline $5-6 \mathrm{~km}$ & 924 & 5.5 & 1,855 & $20 \%$ & 371 \\
\hline Total & & & & & 906 \\
\hline
\end{tabular}

\subsubsection{National programs for cycling}

Denmark and the Netherlands are the countries where people cycle the most. It is characteristic for these two countries, however, that suggestions about how to stimulate cycling are rarely raised. Even though these countries in principle have a cycling policy that encourages people to cycle more, cycling is only cursorily mentioned in national campaigns for 
better health and more exercise. Moreover, investments to make cycling more attractive are primarily left in the hands of local municipalities. In contrast to Denmark and the Netherlands, countries such as Norway, Great Britain, Belgium (especially Flanders), and Canada have a political agenda on which cycling is listed as a means to improve health in general and to stimulate physical exercise. Efforts in Great Britain and Canada, where there are relatively few cyclists, have as yet only rarely resulted in practical political initiatives. But in Norway, and especially in Flanders, large federal funds, earmarked for stimulating cycling, have been channelled to municipalities.

The above-mentioned countries have all set political goals for how much cycling should increase within a specified time frame. Such a goal was also formulated in Denmark in 1993, but since then it seems to have been forgotten. In Denmark there are plans to improve health in general, and to reduce illnesses that stem from physical inactivity and obesity. Cycling is mentioned in these plans as a means, but it does not play a prominent role. Moreover, the ministry of traffic is practically absent from both the development and realization of such plans. After the change of government - to a liberal-conservative one - in 2001, efforts to diminish physical inactivity and obesity were prioritized, but at the same time all government funds to promote cycling were cancelled. And no compensation has been given.

\subsubsection{Cities with special cycle-initiatives}

In addition to all this, the Danish report describes nine cases - three concerning Danish cities/regions, and six concerning foreign cities/regions where special initiatives have been taken to promote cycling. The case studies show that there are many different factors that may successfully contribute to increasing cycling. Among these are:

- A strong political commitment to increase cycling

- Enthusiastic and committed civil servants and officials who can support concrete projects with political accept

- The existence of regional funding or road user charge funds that can finance local cycle initiatives

- The implementation of concrete plans, and long term commitment to these plans

Moreover, focus on cycling as a means to reduce both traffic congestion and health problems seems to be increasing. Improving traffic safety is not the main argument anymore for engaging in the issue of cycling. 


\subsubsection{Recommendations}

In light of the analyses it is recommended that:

- Cycling must have higher priority in campaigns promoting physical exercise for children and adults.

- The Ministry of Traffic together with The Ministry of Health and the Ministry of Environmental Affairs must be involved in the realization of projects to increase physical exercise.

- A concrete plan must be formulated, detailing how children can be urged to cycle more. This must include tightening traffic regulations and speed control near schools, sports centres, and other places frequented by children.

- A plan must be formulated to reduce air pollution, especially in the form of ultra fine particles, in cities, in order to provide a safer environment for the cyclists.

- National funding must be reintroduced. These funds should be earmarked, so that municipalities interested in running cycle campaigns, developing bicycle infrastructure, and improving safety can apply for financial resources to do so.

- Cycling campaigns and communication of knowledge on how cycling can be increased should be centrally coordinated.

- Future economical analyses concerning traffic should include effects on cycling and walking, and indirect consequences for public health. Such calculations should also influence whether traffic projects are prioritized in governmental strategies concerning the environment. 


\subsection{Transport, Health and Environment Pan-European Programme (THE PEP)}

\section{Harry Rutter, WHO.}

\subsubsection{Policy framework 2002}

The PEP is a policy framework adopted by the 2nd High Level Meeting on Transport, Environment and Health (Geneva, 5 July 2002). It was launched at the World Summit on Sustainable Development as one of the partnerships on "Sustainable development in action". The PEP consolidates and rationalizes work carried out under the auspices of UNECE and WHO/Europe.

The PEP provides a framework for equal representation and full ownership by the transport, health and environment sectors, a unique example of cooperation among different organizations and an implementationoriented approach through concrete projects (WHO, 2005a and b). The key priority areas of the PEP are:

- Integration of environmental and health aspects into transport policies and decisions

- Shift of the demand for transport towards more sustainable mobility

- Urban transport issues

- Cross cutting issues:

- Specific needs of the EECCA and South-Eastern European countries

- Ecologically particularly sensitive areas of the region

The programme of work for 2003-2005 was adopted at 1st (2003) and 2nd (2004) Sessions of THE PEP Steering Committee:

- THE PEP Clearing House on Transport, Environment and Health

- Sustainable and healthy urban transport and land-use planning

- Transport Related Health Impacts and their Costs and Benefits with a Particular Focus on Children

- Establishment of indicators to monitor integration of environmental and health aspects into transport policies

- Guidance on institutional arrangements and mechanisms for integrated policy and decision-making

- Promotion of safe walking and cycling in urban areas 


\subsubsection{Promotion of safe walking and cycling in urban areas}

WHO Europe is working, together with the UNECE and under THE PEP framework, in the project "Promotion of safe cycling and walking in urban areas", which started in 2004. The overall objective of the project is to promote and improve safe conditions for walking and cycling in urban areas, in combination with public transport and to facilitate a modal shift towards cycling and walking.

The European Conference of Transport Ministers (ECMT) has investigated the role of national cycling policies in the context of Sustainable Urban Travel project. In this respect the ECMT has adopted Ministerial Declaration (2004) on promotion of cycling. This declaration will support implementation of those recommendations that ECMT ministers adopted in 2002 on implementing sustainable urban travel policies. The progress of this work will be reviewed again at the ECMT Ministerial meeting in Dublin in 2006.

There is a largely untapped potential for cycling and walking as means of daily transport. More than $30 \%$ of trips made in car in Europe cover distances of less than $3 \mathrm{~km}$ and $50 \%$ of less than $5 \mathrm{~km}$. These distances can be covered within 15-20 minutes by bicycle and 30-50 minutes by brisk walking. The "average European citizen" cycles ca. $0.5 \mathrm{~km}$ and travels by car $27.5 \mathrm{~km}$ daily.

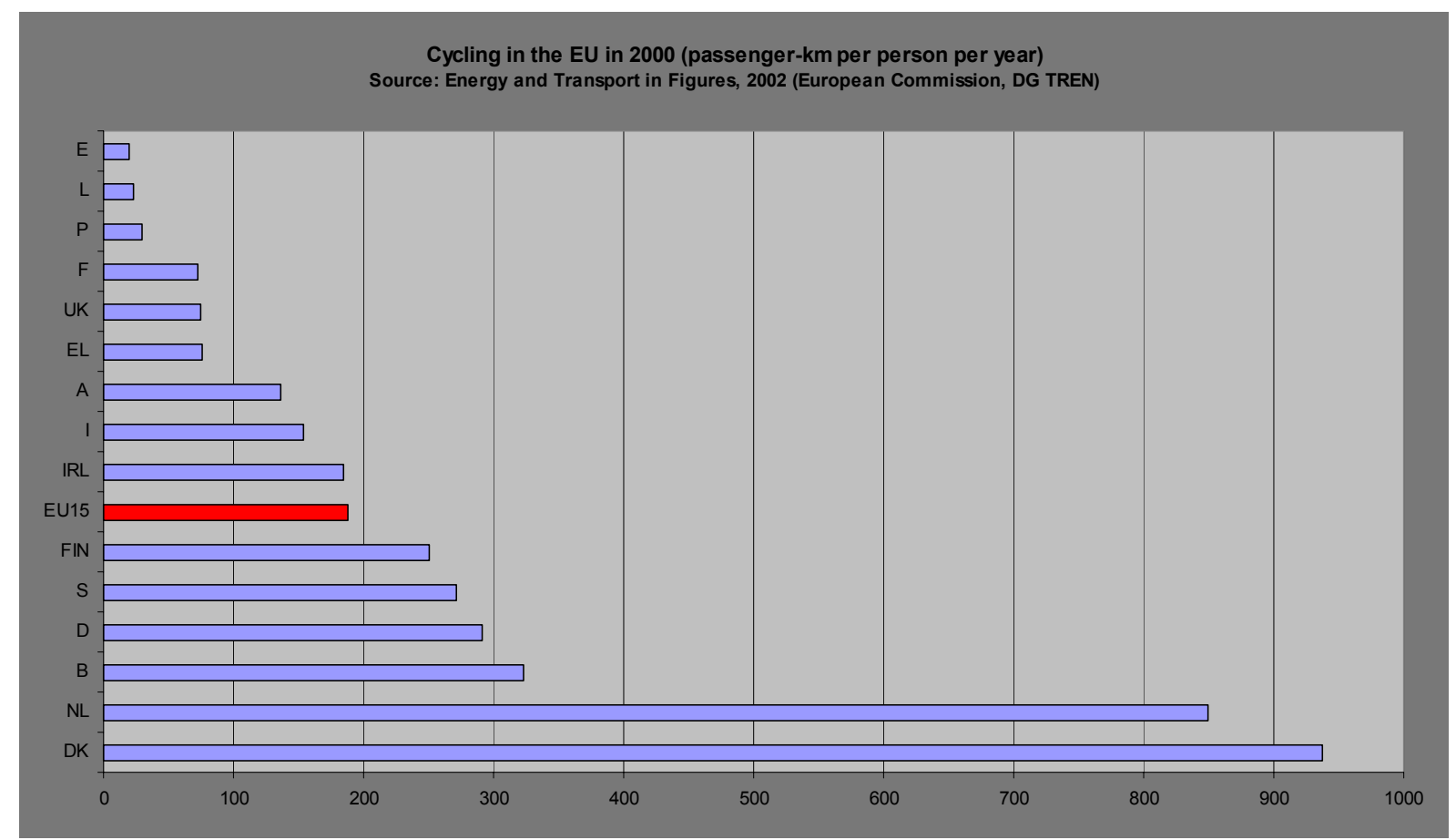


On a global scale, physical inactivity is estimated to yearly cause:

- 1.9 million deaths

- 19 million Disability Adjusted Life Years (DALY, which is an indicator that combines years of life lost due to premature mortality and years of life lived with disability)

- $\quad 10-16 \%$ of cases of breast cancer, colon and rectal cancers, and diabetes mellitus

- $22 \%$ of ischemic heart disease

The proportion of deaths attributable to physical inactivity in Europe is 5$10 \%$ (ca. 600,000 deaths/year).

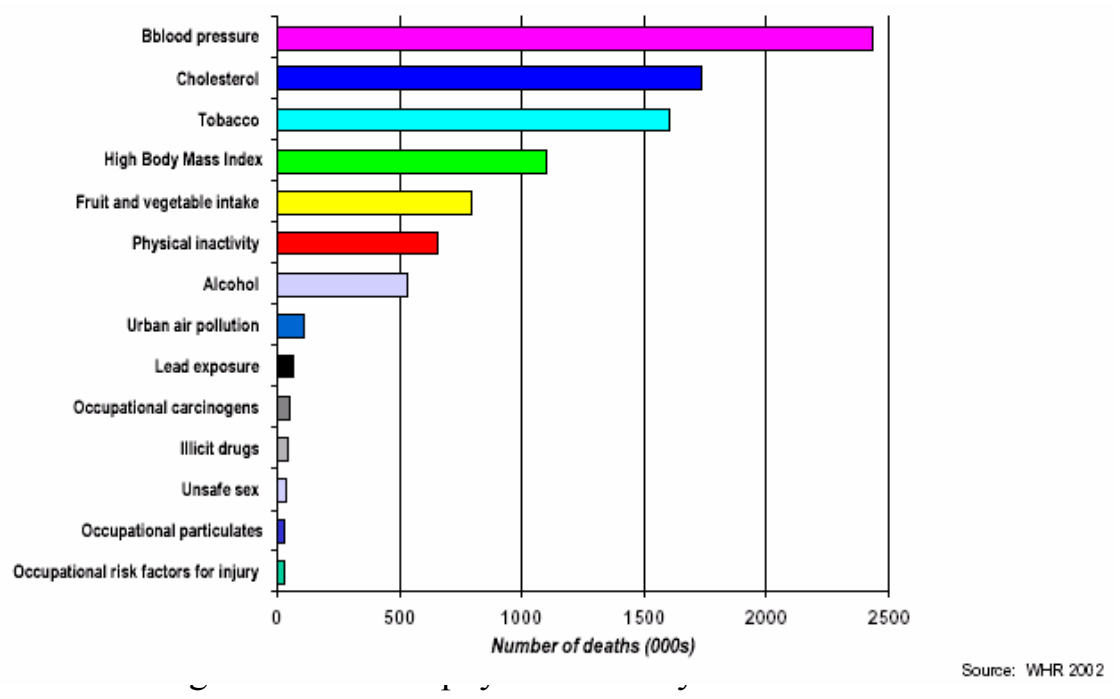

health benefits of physical activity (30 minutes/day) are according to WHO:

- A $50 \%$ reduction in the risk of developing coronary hearth disease, non-insulin-dependent diabetes and obesity

- A $30 \%$ reduction in the risk of developing hypertension

- A decline in blood pressure among hypertensive people

- Helping to maintain bone mass and protecting against osteoporosis

- Improving balance, co-ordination, mobility, strength and endurance

- Increasing self-esteem, reducing levels of mild to moderate hypertension and promoting overall psychological well-being

- Reductions in the risk of colon cancer

In order to promote cycling it is necessary to overcome the "barrier effect". People do not choose to cycle or walk if they are afraid of accidents. Around $90 \%$ of parents are worried about traffic hazards on their child's journey to school.

There seems to be a relationship between cycle risks and distanced travelled. In countries where cycling is promoted, risks for cyclists are lower. 


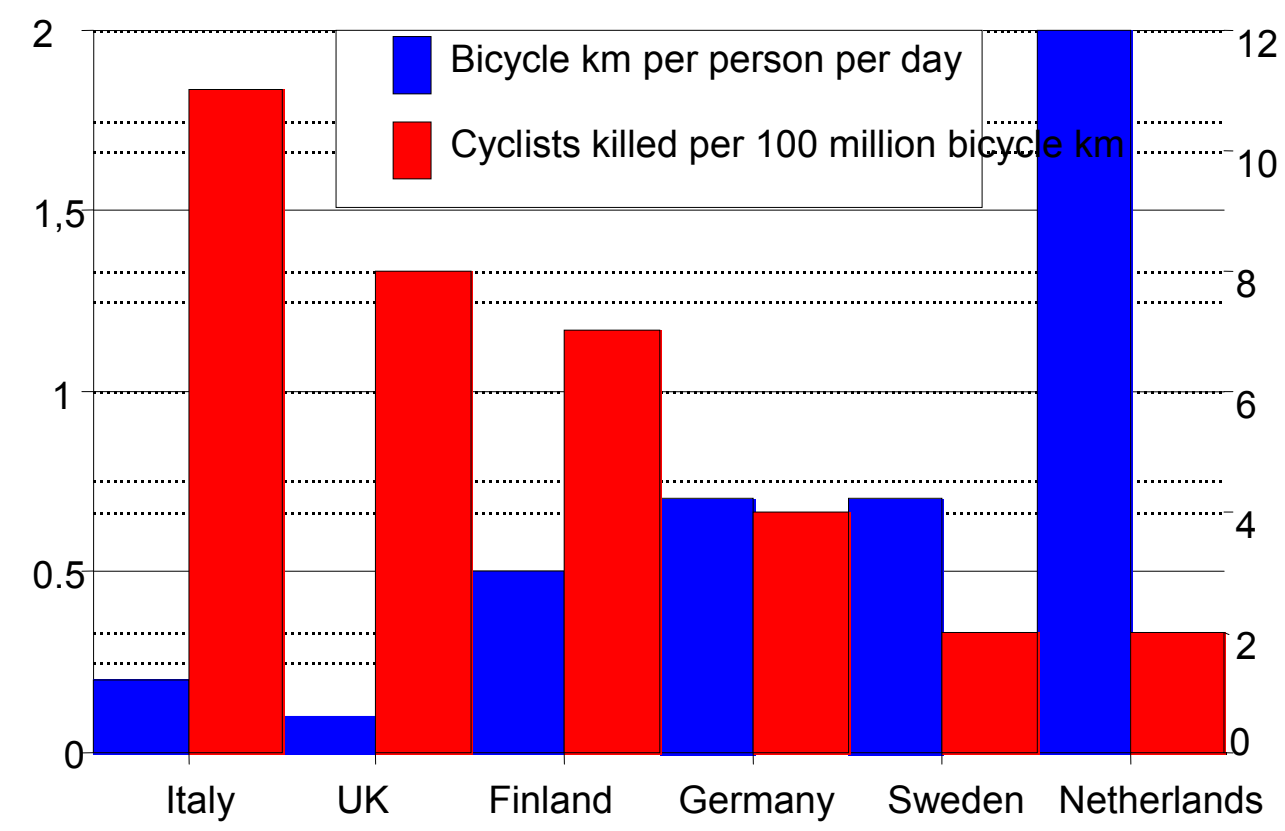

The specific objectives of the work in the project are:

- Exchange and disseminate existing good practices in promoting safe conditions for walking and cycling in urban areas;

- Closer alignment between transport policies of EU/EEA countries and EECCA countries (Eastern Europe, the Caucasus and Central Asia);

- Promote the use of CBA of transport-related policies and infrastructures that take into consideration the possible health benefits resulting from safer walking and cycling;

- Assess the potential of increased walking and cycling in reducing road transport and its negative environmental and health impacts in urban areas;

- Develop guidance on how to assess the costs of health effects in relation to walking and cycling, building on:

- work carried out in the context of THE PEP project "Transport related health impacts and their costs and benefits in particular as regards the children",

- work underway in Nordic countries

- other initiatives presently under way in the region;

- Contribute to the further development of WHO guidelines to carry out HIA of walking and cycling

The project will take stock from relevant on-going activities, bring them together and disseminate: 
- Swiss report on "Transport and Physical Activity" launched in Budapest

- Establishment of the European Network for the Promotion of Health Enhancing Physical Activity with secretariat at the WHO;

- ECMT report on National cycling policies;

- Work of Nordic Council in the development of guidance for assessing the costs and benefits of interventions which promote cycling and walking (workshop in Stockholm on 1-2 Feb)

- UK SEPHO/DH work on quantifying the health and economic effects of changes in cycling

\subsubsection{Next steps}

The next steps will be to set up a task force of interested member states; develop a review of existing relevant studies and approaches to quantify the health effects and conduct cost-benefit analyses; arrange a Workshop of experts to identify possible common methodology (health end-points; economic valuations) and to develop and publicise of a report with methodological recommendations.

Relevant events in 2005 are Velo-City in Dublin, 31 May - 4 June; Walk21 and satellite symposium in Magglingen/Zurich 18-23 Sep.

\subsection{Discussions on the role of CBA in decision making}

This section is based on the discussions during the second day of the Nordic seminar on the $2^{\text {nd }}$ February, 2005.

\subsubsection{Will the use of CBA improve decision making?}

Socio-economic appraisal is growing in importance. The CBAs made on the system level in Norway, Finland and Denmark have indicated very high profitability in cycle infrastructure.

The Saelensminde report showed tremendously high health effects of cycling. The result has triggered the interest for health benefits and cycling among the politicians. The Norwegian Road Administration has however been sceptical.

CBA has the potential to improve decision-making, but there are several uncertain assumptions involved, which have to be tackled.

In Finland, the CBA framework for road investments is used also for cycling infrastructure. The municipalities decide themselves if they use the framework or not. In Sweden health effects should be included in the CBA framework as in the other Nordic countries.

It is important that CBA will be used also on the regional level. In Norway no CBA's have been made in the municipalities so far. Urban 
regions use transport models, but not for cycling. A step forward would be to also include cycling when modelling urban infrastructure. But to be practical, it must also be possible to make a CBA without complex transport models.

\subsubsection{How can CBA be used to make policy?}

Politicians are sensible. If CBA supports policy-making, then it will also be used more frequently. The politicians believe in the health effects of cycling. The figures that have been presented of obesity, physical inactivity and health risks have been convincing.

CBA is important because it can influence the Treasury. It is therefore important to influence the appraisal sheets of the Ministries and the Road Authorities.

The driving force to make policy out of CBA of cycling is the health and environmental effects. An idea is to make a comprehensive study on bicycle investments to accelerate the development in Sweden. It is necessary with a holistic approach to understand the level of biking. Two PhDstudents can investigate 10-30 cities. Include interviews with car drivers. With such a study it will be evident that there is a close connection between investments and focus on cycling and the environmental attractivity of the city centre.

ECMT has projects for sustainable transport development, in which cycling plays an important role. 


\section{Conclusions and recommen- dations}

\subsection{Conclusions}

a) Main effects of cycling

The participants in the seminar agreed that comfort, security, public health effects, accidents, travel time and costs of cycling are the main direct effects that should be included in a CBA of cycling.

Other effects as the reduction of external costs (maintenance, emissions, noise, accidents etc) for motorised transports, consequences for public transport, effects on transport of school children and short-term absence from work should also be included if these effects can be quantified. The assumptions made in the case studies are however uncertain. More evidence is needed to qualify these assumptions.

b) Health benefits.

The participants agreed that the Public health benefits are great if it is possible to directly address inactive persons. The magnitude of the assumed health effects of activating inactive persons is similar between the countries. All countries also seem to agree that 30 minutes of cycling per day is necessary to achieve the health benefits. The link between measures to improve cycling and activating inactive people is however rather weak and more studies are needed to qualify this assumption. For policy development purposes and to justify investments in infrastructures for cyclists and pedestrians, there is a need to better identify "who gets on the bicycle" and what is needed to make more people choosing human powered vehicles.

The assumption in the Norwegian study that short-time absence for activated inactive persons can be reduced with a fifth (one percentage from $5 \%$ to $4 \%$ ) seems reasonable. Evidence from Odense showed a corresponding reduction of $6 \%$ for all cyclists altogether.

Although a reasonable concensus was observed during the seminar, some of the decisions/assumptions taken by the different CBA approaches should be further discussed (e.g. should potential risk reductions in cancer be included, in addition to $\mathrm{CVD}^{9}$, hypertension, diabetes Type II and angina? Which age band should be looked at?). Ideally, the build-

${ }^{9}$ Cardiovascular disease 
ing of this scientific consensus should be facilitated by organizing an international workshop addressing these points and coming up with a proposed methodological approach to the quantification of the health effects of changes in transport policy.

Similarly, some more discussion should take place on the effects of "do nothing" policies, as there can be a justification to include in the analysis also the savings which are resulting from just maintaining the same amount of cycling and walking (e.g. see Swiss study showing the health savings brought by keeping the same levels of physical activity)

c) Comfort and security.

There is also an agreement that effects on comfort and security also can play a big role in CBA of cycling. Just a few studies have directly addressed this issue. More evidence is needed to determine the correct magnitude of these effects.

\section{d) Demand}

It is very important for CBA of cycling to understand the demand effects of improving cycle infrastructure and comfort values of cycling. Understanding demand is the key to the health benefits as well as the effects on comfort and security. More studies in this field are necessary.

\section{e) Accidents}

It is important to control if accidents are increased or reduced with more cycling. No such effects have been assumed in the CBA made on the strategic level. There seems however to be a trend towards less cycle accidents in absolute numbers as cycling is increased.

\section{f) Uncertain assumptions}

The assumptions that transport of school children and income of public transport are substantially affected by increased cycling should be reconsidered as the evidence is rather weak.

\section{g) Unit costs in CBA of cycling}

Average values used in the Nordic studies are summarised in the table below. Values per trip or per hour have been transformed to distancerelated values if possible. The values to the right are alternative values, which should correspond to the values to the left.

There seems to be no big differences between the countries apart from travel time. A higher value for cyclists can be justified as many people choose not to cycle based on comfort reasons. A lower value for cyclists can be justified as cycling is used for shorter trips and for leisure reasons. These differences should be sorted out. Reduced travel time is seldom the 
most important impact when improving cycle infrastructure. It is however important to control the value of time for cycling, cost and time elasticities in comparison with other transport modes.

\begin{tabular}{|c|c|c|}
\hline EFFECT & AVERAC & VALUES \\
\hline Comfort & $€ 0-0.3$ per cyclekm & \\
\hline Insecurity & $€ 0.2$ per cyclekm & \\
\hline $\begin{array}{l}\text { Public health } \\
\text { benefits }\end{array}$ & $\begin{array}{l}€ 900 \text { per year (activated } \\
\text { person) }\end{array}$ & $\begin{array}{l}€ 350 \text { per year or } € 0.15 \text { per } \\
\text { cyclekm (average additional } \\
\text { commuter) }\end{array}$ \\
\hline $\begin{array}{l}\text { Short-term } \\
\text { absence }\end{array}$ & $\begin{array}{l}€ 2500 \text { per year (employed } \\
\text { activated person) }\end{array}$ & $\begin{array}{l}€ 500 \text { per year (average } \\
\text { additional commuter) }\end{array}$ \\
\hline External costs & $\begin{array}{l}€ 0.05 \text { per vehiclekm (reduced } \\
\text { car traffic) }\end{array}$ & \\
\hline Parking & $\begin{array}{l}€ 40-80 \text { per month and car } \\
\text { (reduced parking) }\end{array}$ & $\begin{array}{l}€ 0.05-0.10 \text { per vehiclekm } \\
\text { (reduced car traffic) }\end{array}$ \\
\hline Public transport & $\begin{array}{l}€ 0: 25 \text { per personkm (reduced } \\
\text { income) }\end{array}$ & \\
\hline Cost of cycling & $€ 0.05$ per cyclekm & \\
\hline School children & $\begin{array}{l}€ 0.5 \text { per childkm (reduction } \\
\text { in school bus transport) }\end{array}$ & \\
\hline Accidents & $\begin{array}{l}€ 85000 \text { per injury accident } \\
\text { (link) }\end{array}$ & $\begin{array}{l}€ 200000 \text { per injury accident } \\
\text { (junction) }\end{array}$ \\
\hline $\begin{array}{l}\text { Travel time for } \\
\text { cyclists }\end{array}$ & $\begin{array}{l}€ 5-9 \text { per cyclehour (varies } \\
\text { with standard of track) }\end{array}$ & \\
\hline Delay & $\begin{array}{l}€ 0.25 \text { per minute (road } \\
\text { crossing) }\end{array}$ & \\
\hline
\end{tabular}

h) Potential of cycling

There is a big potential for cycling to improve public health, the environment and the attractivity of the cities. It is assumed in the Danish case study that the number of cycle trips shorter than $3 \mathrm{~km}$ can increase with $50 \%$ or more.

i) Promotion of physical activity

As the problem of obesity and physical inactivity is growing, there will be a great chance to promote cycling. In order to promote cycling it is necessary to make cycling safer and more attractive in the future. 


\section{j) Attractiveness of the city}

Cycling can add to the attractiveness of the city. Big changes as in Odense can however only be achieved if positive measures to promote cycling are combined with impedances for motorised traffic.

\subsection{Recommendations}

a) Disseminate the results

It important to disseminate the result of the 'CBA of cycling' seminar. The Nordic Council is recommended to open a website where you can find the summary report and the contributions to the seminar and the national reports. There should also be a link to the report at the PEP and ECMT websites.

b) Exchange experience

It is recommended to establish a network where interested parties can exchange views in methodological and policy issues of CBA of cycling. Such a network can accelerate dissemination of results and the development of the CBA method. A possibility is to bring this initiative to the newly established network for the promotion of health enhancing physical activity in Europe (HEPA Europe).

c) Co-operate in research

We need more research in order to come close to a 'final' handbook of CBA of cycling. The Nordic countries and WHO are recommended to cooperate to get reliable and convincing results concerning demand effects, valuation of comfort and security and realistic health effects of cycling.

d) Develop the CBA handbooks

A cycling handbook is needed to prioritise cycle investments and other cycling measures. All countries are recommended to check their handbooks and develop their approaches further based on the result of the methodological discussion.

e) Test the approach

Although some factors are uncertain, it is recommended to test the CBA method already today. The most reasonable application is probably on a strategic level for a network or a programme in a city, regarding the data needed to fulfil the CBA. The process of working with CBA is important to understand the real benefits of cycling and can also add to the development of the method. 


\section{f) Improve data}

Data concerning cycling performance, flows, standard of cycle paths etc are needed to enable reliable CBA's of cycling. Fixed counting places also include cyclists in Denmark. A system of cycling traffic counts is under way in Norway.

The quantification of cycling and walking (i.e. monitoring) is a critical weakness in many countries All countries are recommended to check how data can be improved to allow fore comprehensive use of CBA of cycling.

\section{g) Involve local autorities}

There is a need to reach local authorities and have them involved in the key decisions. In order to obtain a widespread use, methods should be transparant and understandable. It is recommended to develop some reasonably sound "model" (spreadsheet) to facilitate the picking-up of CBA of cycling by local authorities.

\section{h) Promote CBA of cycling}

The time is ripe for CBA of cycling, if we are critical and accept that we need more knowledge. The CBA of cycling should be further promoted nationally, in ECMT and other international fora. The knowledge that has been put together should also be used to further develop national health strategies and strategies concerning sustainable development. 



\section{References}

Andersen et al. (2000) All-cause mortality associated with physical activity during leisure time, work, sports, and cycling to work. Archives of Internal Medicine 2000, 160, 1621-1628.

Arousell P. (2005) CBA's Role in Swedish Planning.

Ege C et al (2005). Cykling, miljø, motion og sundhed. Det ökologiske råd.

Hyden C et al. (1998) WALCYNG, University of Lund 1998.

Jacobsen PL. (1998) Injury Prevention 2003;9:205-209

Krag T (2005) Cost Benefit Analysis of Cycling - Denmark. Nordic Council of Ministers' seminar Stockholm. February 1-2, 2005.

Lind G (2005) Benefits and costs of bicycle infrastructure. Nordic Council of Ministers' seminar Stockholm. February 1-2, 2005.

Metsäranta H. (2004) Finnish guidelines for the assessment of walking and cycling projects. Presentation at NTF seminar Copenhagen, December 7-8, 2004

Naturvårdsverket (2005) Vilken är den samhällsekonomiska nyttan med cykeltrafikåtgärder? Försök till förbättring av beslutsunderlaget.

National Audit Office (2001). Tackling Obesity in England, London. Available from URL: http://www.nao.org.uk/pn/0001/0001220.htm

Det økologiske råd (2005). Trafik, miljø, motion og sundhed - konkrete cases fra byer og regioner i Europa.

Paffenbarger et al. (1986) Physical activity, all-cause mortality, and longevity of college alumni. NEJM 1986;314:605-13

Rutter, H (2005) Valuing the mortality benefits of regular cycling. Nordic Council of Ministers' seminar Stockholm. February 1-2, 2005.
Saari R (2005) Cycling policy in Finland and relevance of CBA for the policy. Nordic Council of Ministers' seminar Stockholm. February 1-2, 2005.

Saelensminde, K. (2002) Gang- och sykkelvegnett i norske byer. Nytte- kostnadsanalyser inkludert helseeffekter og eksterne kostnader av motorisert vegtrafikk, ТØI rapport 567/2002.

Saelensminde, K. (2004) Costbenefit analyses of walking and cycling track networks taking into account insecurity, health effects and external costs of motorized traffic. Transportation Research Part A 38 (2004) 593-606.

Statens vegvesen. (2003) National Cycling Strategy - Making Cycling Safe and Attractive. Policy document, May 2003

The Stationery Office (2004) Securing good health for the whole population: the Wanless report, London.

Tervonen J. and Oja P. (2005) Health benefits of walking and cycling in transport appraisal methodological issues. Nordic Council of Ministers' seminar Stockholm. February 1-2, 2005.

Transport, Health and Environment Pan-European Programme (THE PEP). (2005a) An overview. Nordic Council of Ministers' seminar Stockholm. February 1-2, 2005.

World Health Organisation (2005b) Promotion of safe walking and cycling in urban areas. Nordic Council of Ministers' seminar Stockholm. February 1-2, 2005. 



\section{Appendix - Seminar Programme}

\section{CBA of cycling - current experience in the Nordic countries}

\section{February 1 - Methods for CBA of cycling}

\begin{tabular}{|l|l|}
\hline $10.00-$ & Introduction, Sven Hunhammar \\
13.00 & $\begin{array}{l}\text { Norway, Kjartan Saelensminde (absent) } \\
\text { Sweden, Gunnar Lind } \\
\text { Finland, "Health benefits of walking and cycling in } \\
\text { transport assessment - methodological issues", Juha } \\
\text { Tervonen } \\
\text { Denmark, Thomas Krag } \\
\text { UK, 'Valuing the mortality benefits of regular cycle } \\
\text { commuting in England' Harry Rutter }\end{array}$ \\
\hline Lunch & $\begin{array}{l}\text { Discussions on methodological conclusions and semi- } \\
\text { nar recommendations. } \\
\text { Special focus on: Demand, Comfort and Health ef- } \\
\text { fects. }\end{array}$ \\
\hline Dinner & $\begin{array}{l}19.00 \text { at Café Duvals bakficka: Pressklubben, Vasaga- } \\
\text { tan } 50 .\end{array}$ \\
\hline
\end{tabular}


February 2 - Policy relevance

\begin{tabular}{|l|l|}
\hline $\begin{array}{l}\text { 9.00- } \\
12.00\end{array}$ & Introduction, Sven Hunhammar \\
& $\begin{array}{l}\text { Norway, Gyda Grendstad, National cycle strategy. } \\
\text { Sweden, Patrik Arousell, VV } \\
\text { Finland, Risto Saari } \\
\text { Denmark, ? } \\
\text { WHO, THE PEP project "Safe cycling and walking", } \\
\text { Harry Rutter }\end{array}$ \\
\hline $\begin{array}{l}\text { Lunch } \\
13.00-\end{array}$ & $\begin{array}{l}\text { Discussions on the role of CBA in decision making } \\
\text { and planning for cycling. } \\
\text { Drafting of seminar conclusions. }\end{array}$ \\
\hline
\end{tabular}




\section{Participants:}

Elisabeth Idar Angelov., SIKA, Sweden

Patrik Arousell, VV, Sweden

Bo Dellensten, Cykelbranschrådet, Sweden

Liselotte Schäfer Elinder, Folkhälsoinstitutet, Sweden

Stella Fare, Cykelfrämjandet, Sweden

Gyda Grendstad, National cycle strategy, Norway

Sven Hunhammar, SEPA, Sweden

Christer Hydén, LTH, Sweden

Thomas Krag, Mobility Advice, Denmark

Gunnar Lind, Movea Trafikkonsult, Sweden

Mari Miettinen, Health Department, Finland

James Odeck, Statens Vegvesen, Norway

Ulf Person, IHE, Sweden

Harry Rutter, WHO/ South East Public Health Observatory, UK.

Risto Saari, Ministry of Transport and Communication, Finland

Juha Tervonen, JT-Con, Finland 